\title{
Indicatoren aansluiting onderwijs-arbeidsmarkt MDGO : enkele arbeidsmarktindicatoren op basis van de RUBS-data
}

Citation for published version (APA):

de Grip, A., van der Velden, R. K. W., \& Wieling, M. (1991). Indicatoren aansluiting onderwijsarbeidsmarkt MDGO : enkele arbeidsmarktindicatoren op basis van de RUBS-data. Researchcentrum voor Onderwijs en Arbeidsmarkt, Faculteit der Economische Wetenschappen. ROA Reports No. 2 https://doi.org/10.26481/umarep.1991002

Document status and date:

Published: 01/01/1991

DOI:

10.26481/umarep.1991002

Document Version:

Publisher's PDF, also known as Version of record

Please check the document version of this publication:

- A submitted manuscript is the version of the article upon submission and before peer-review. There can be important differences between the submitted version and the official published version of record.

People interested in the research are advised to contact the author for the final version of the publication, or visit the DOI to the publisher's website.

- The final author version and the galley proof are versions of the publication after peer review.

- The final published version features the final layout of the paper including the volume, issue and page numbers.

Link to publication

\footnotetext{
General rights rights.

- You may freely distribute the URL identifying the publication in the public portal. please follow below link for the End User Agreement:

www.umlib.nl/taverne-license

Take down policy

If you believe that this document breaches copyright please contact us at:

repository@maastrichtuniversity.nl

providing details and we will investigate your claim.
}

Copyright and moral rights for the publications made accessible in the public portal are retained by the authors and/or other copyright owners and it is a condition of accessing publications that users recognise and abide by the legal requirements associated with these

- Users may download and print one copy of any publication from the public portal for the purpose of private study or research.

- You may not further distribute the material or use it for any profit-making activity or commercial gain

If the publication is distributed under the terms of Article $25 \mathrm{fa}$ of the Dutch Copyright Act, indicated by the "Taverne" license above, 


\title{
INDICATOREN AANSLUITING ONDERWIJS - ARBEIDSMARKT MDGO \\ - Enkele arbeidsmarktindicatoren op basis van de RUBS-data -
}

ROA-R-1991/2

\begin{abstract}
A. de Grip
R.K.W. van der Velden

M.H. Wieling
\end{abstract}

RESEARCHCENTRUM VOOR ONDERWIJS EN ARBEIDSMARKT

Faculteit der Economische Wetenschappen

Rijksuniversiteit Limburg

Maastricht, maart 1991 


\section{CIP-GEGEVENS KONINKLIJKE BIBLIOTHEEK, DEN HAAG}

Grip, A. de

Indicatoren aansluiting onderwijs-arbeidsmarkt MDGO; enkele arbeidsmarktindicatoren op basis van de RUBS-data/ A. de Grip, R.K.W. van der Velden, M.H. Wieling. - Maastricht : Researchcentrum voor Onderwijs en Arbeidsmarkt, Faculteit der Economische Wetenschappen, Rijksuniversiteit Limburg. - (Rapport / Researchcentrum voor Onderwijs en Arbeidsmarkt, ISSN 0922-8098; 1991/2

Met lit. opg.

ISBN 90-5321-051-2 geb.

Trefw.: MDGO en arbeidsmarkt 


\section{INHOUDSOPGAVE}

Bladzijde

VERANTWOORDING

1. INLEIDING 1

1.1. Doelstellingen 1

1.2. Onderzoeksopzet 2

2. RUBS-DATA 4

2.1. Dekkingsgraad en respons 4

2.2. Algemene kenmerken van de MDGO-populatie 5

3. WERKLOOSHEID EN WERKZEKERHEID VAN MDGO-ERS 8

3.1. Werkloosheid onder MDGO-ers 8

3.2. Mate van werkzekerheid voor MDGO-ers 12

4. FUNCTIENIVEAU EN INKOMEN VAN DE WERKENDE MDGO-ERS 15

4.1. Functieniveau van de werkende MDGO-ers 15

4.2. Inkomen van de werkende MDGO-ers 18

5. FLEXIBILITEITSINDICATOREN 22

5.1. Gini-Hirschman coëfficiënt 22

5.2. Beroepenspreiding van opleidingen 25

5.3. Branchespreiding van opleidingen 30

5.4. Opleidingspreiding van beroepen 33

$\begin{array}{lll}\text { 6. BESLUIT } & 36\end{array}$

$\begin{array}{ll}\text { LITERATUUR } & 41\end{array}$ 


\section{VERANTWOORDING}

Deze studie is uitgevoerd in het kader van de ontwikkeling van het informatiesysteem onderwijs-arbeidsmarkt van het Researchcentrum voor Onderwijs en Arbeidsmarkt (ROA), dat onder meer kan worden gebruikt bij de studie- en beroepskeuzevoorlichting aan leerlingen in het voortgezet en hoger onderwijs.

In 1988 werden in een werkdocument enkele indicatoren besproken. In deze studie zullen een aantal van deze indicatoren worden gekwantificeerd. Daarbij zal ook worden nagegaan welke mogelijkheden het RUBS-databestand biedt voor het verder verbijzonderen van de reeds ontwikkelde indicatoren naar vakrichting.

Het onderzoek werd, onder leiding van dr. A. de Grip en drs. R.K.W. van der Velden, uitgevoerd door drs. M.H. Wieling. 


\section{INLEIDING}

\subsection{Doelstellingen}

In opdracht van het Ministerie van Onderwijs en Wetenschappen werkt het Researchcentrum voor Onderwijs en Arbeidsmarkt (ROA) aan de ontwikkeling van een informatiesysteem ten behoeve van de studie- en beroepskeuzevoorlichting aan leerlingen en studenten in het voortgezet en hoger onderwijs. Prognoses van de arbeidsmarktperspectieven van beroepen en opleidingen vormen een van de belangrijkste onderdelen van het informatiesysteem. Prognoses zijn immers vooral bedoeld om de kans op het vinden van een eerste baan na het afronden van een opleiding aan te geven. Daarnaast bestaat eveneens een behoefte aan arbeidsmarktindicatoren (De Grip, Heijke en Dekker, 1989). Deze indicatoren verschaffen enerzijds een indicatie van de latere mogelijkheden op de arbeidsmarkt en de risico's die men daarbij loopt. Anderzijds is er ook behoefte aan arbeidsmarktindicatoren met betrekking tot de huidige arbeidsmarktsituatie. In het algemeen kunnen dergelijke flexibiliteitsindicatoren een goed beeld geven van het actuele functioneren van het onderwijs met betrekking tot de arbeidsmarkt. In De Grip en Heijke (1988) wordt geprobeerd in deze behoefte te voorzien door een inventarisatie te geven van de verschillende soorten arbeidsmarktindicatoren die kunnen worden geconstrueerd.

Het onderhavige rapport heeft in feite een tweetal doelstellingen. Enerzijds beoogt deze studie een aantal belangrijke, door De Grip en Heijke (1988) reeds besproken, arbeidsmarktindicatoren empirisch in te vullen aan de hand van de schoolverlatersdata verkregen uit de RUBS-enquête 1989 (Registratie van Uitstroom en Bestemming van Schoolverlaters). Anderzijds wordt getracht enkele belangrijke voorbeelden te geven van de mogelijkheden die schoolverlatersdata, zoals die in het RUBS-pilotproject zijn verzameld, bieden voor het verrijken van het ROAinformatiesysteem onderwijs-arbeidsmarkt. De meer direct interpreteerbare uitkomsten van de RUBS-enquête blijven daarbij buiten beschouwing. Hiervoor wordt verwezen naar de diverse onderzoeksrapporten van de Contactcentra Onderwijs en Arbeid (COA) en het landelijk onderzoeksverslag van Van Laarhoven en Waslander (1990). Eveneens wordt niet ingegaan op de mogelijkheden die de RUBS-data bieden voor het verbeteren en mogelijk verbijzonderen van de arbeidsmarktprognoses (zie De Grip en Van Dam, 1990).

In 1988 hebben een aantal Contactcentra Onderwijs en Arbeid al een beperkt uitstroomonderzoek uitgevoerd. In de loop van 1988 heeft het project een meer landelijk accent gekregen en is er gestart met een pilotstudie. Het RUBS-project is een grootschalig onderzoekprogramma waarmee een periodiek herhaalde registratie van de uitstroom en 
bestemming van schoolverlaters uit het voltijd onderwijs wordt beoogd. Het voornaamste onderdeel vormt een schriftelijke enquête onder schoolverlaters, een klein jaar na het beëindigen van de opleiding. In deze enquête worden zowel de gediplomeerde als de voortijdige schoolverlaters meegenomen.

Met het RUBS-project wordt getracht te voorzien in de behoeft aan informatie uit twee invalshoeken (Van Laarhoven en Waslander, 1990):

- 'De bestemming van schoolverlaters van opeenvolgende cohorten, bezien vanuit de doelstellingen van de scholen en opleidingstypen vanwaar zij uitstromen. Hier wordt wel gesproken van het externe rendement van opleidingen;

- De intrede van nieuwkomers op de arbeidsmarkt, bezien vanuit de kwalificatiebehoeften in de maatschappij als geheel en in de verschillende sectoren en beroepsdeelmarkten in het bijzonder.'

In het kader van deze RUBS-pilotstudie 1989 hebben 11 van de 13 COA's (de COA's van Brabant en Limburg hebben nog niet geparticipeerd in dit onderzoek) in het voorjaar van 1989 een enquête gehouden onder schoolverlaters van de jaargang 1987/88. Doordat het onderzoek werd gefinancierd vanuit de diverse regionale bronnen, liep de onderzoeksinspanning die de COA's konden leveren vaak sterk uiteen. Het enige opleidingstype dat door alle deelnemende COA's in het pilotproject kon worden betrokken, is het Middelbaar Dienstverlenings- en Gezondheidszorgonderwijs (MDGO). Vandaar dat deze studie zich concentreert op het invullen van de arbeidsmarktindicatoren met behulp van de data van schoolverlaters uit het MDGO, als voorbeeld van de mogelijkheden die het RUBS-onderzoek biedt voor het construeren van enkele belangrijke arbeidsmarktindicatoren.

\subsection{Onderzoeksopzet}

De opzet van deze studie is als volgt. In hoofdstuk 2 worden enkele algemene resultaten van de dataverzameling besproken. Daarbij vindt echter geen uitgebreide beschrijving plaatsvindt van de RUBS-data. Hiervoor wordt nogmaals verwezen naar het rapport van Van Laarhoven en Waslander (1990), die een uitgebreid verslag hebben geschreven over eveneens de MDGOschoolverlaters in het RUBS-bestand. In hoofdstuk 3 staat de kans op werk centraal. Er wordt ingegaan op de werkloosheid onder de MDGO-schoolverlaters en op de conjunctuurgevoeligheid van de werkgelegenheid in de onderscheiden opleidingsrichtingen. Vervolgens wordt er in hoofdstuk 4 nader ingegaan op het functieniveau behorend bij het beroep dat door de schoolverlaters wordt uitgeoefend en het inkomen dat door de schoolverlaters wordt verdiend. Deze indicatoren zeggen vooral iets over de aard van het werk van de werkende MDGO- 
$-3-$

schoolverlaters. De flexibiliteitsindicatoren worden in hoofdstuk 5 behandeld. Deze indicatoren gaan in op de mobiliteits- en uitwijkmogelijkheden. Tenslotte worden in hoofdstuk 6 de belangrijkste resultaten nogmaals op een rij gezet. 


\section{RUBS-DATA}

\subsection{Dekkingsgraad en respons}

Het doel van het RUBS-onderzoek is, zoals in hoofdstuk 1 reeds werd aangegeven, het krijgen van inzicht in de uitstroom en bestemming van schoolverlaters van een bepaalde jaargang van het voltijd onderwijs. Daarbij moet worden bedacht dat zowel gediplomeerden als ongediplomeerden en zowel de uitstromers die doorleren als degenen die stoppen met voltijd onderwijs als schoolverlater worden getypeerd. Al degenen die in een bepaald cursusjaar op een bepaalde school een voltijd opleiding hebben genoten en het daarop volgende cursusjaar niet meer, worden in het RUBS-project meegenomen.

Het gegevensbestand van het RUBS-pilotonderzoek heeft het karakter van een omvangrijke maar niet erg systematische steekproef (Van Laarhoven en Waslander, 1990). Het gaat daarbij in feite om een tussenvorm van een populatie-onderzoek, waarbij alle schoolverlaters van alle scholen worden benaderd, en een steekproef onderzoek, waarbij op systematische, aselecte wijze een deel van de schoolverlaters wordt geselecteerd.

Omtrent de mate waarin de enquête de totale populatie bestrijkt, de dekkingsgraad, is het volgende bekend. De dekkingsgraad is over het algemeen hoog (gemiddeld 52\%). Er komen echter wel verschillen in dekkingsgraad voor, zowel tussen regio's als tussen opleidingsrichtingen. Derhalve wijkt het RUBS-bestand qua regionale spreiding enigszins af van de totale MDGO-populatie. Er bestaat echter, voorzover valt na te gaan, weinig reden om aan te nemen dat de benadering en deelname van de scholen, althans wat betreft de gediplomeerde schoolverlaters, selectief zou zijn geweest. Daarentegen moeten de resultaten met betrekking tot de ongediplomeerde schoolverlaters echter met grote voorzichtigheid worden geïnterpreteerd. De reden hiervoor is de lage dekkingsgraad onder de voortijdige schoolverlaters. Waarschijnlijk vertegenwoordigen de aangeschreven ongediplomeerde schoolverlaters slechts een kwart tot een derde van de beoogde groep.

Over de respons kan het volgende worden opgemerkt. De gemiddelde respons van de gediplomeerde MDGO-ers is vrij hoog, namelijk $74 \%$, waarbij naar regio en opleidingsrichting enig verschil optreedt. Voor ongediplomeerde MDGO-schoolverlaters bedraagt de respons slechts $43 \%$. Ook hier komen aanzienlijke verschillen voor tussen regio's en opleidingsrichtingen. De resultaten van non-responsonderzoek, uitgevoerd door een aantal COA's, geven echter weinig aanleiding tot de veronderstelling dat de non-respons selectief van aard is (Van Laarhoven en Waslander, 1990). 


\subsection{Algemene kenmerken van de MDGO-populatie}

Binnen het MDGO kunnen de volgende 10 opleidingsrichtingen worden onderscheiden:

- verzorging (VZ);

- sociale arbeid (SA);

- agogisch werk (AW);

- assistenten gezondheidszorg (AG);

- civiele \& consumptief-technische diensten (CCD);

- mode en kleding (MK);

- activiteitenbegeleiding (AB);

- sport en beweging (SB);

- uiterlijke verzorging (UV);

- verpleging (VP).

Het totaal aantal schoolverlaters in het gegevensbestand van het RUBS-pilotproject bedraagt 26509, waarvan 7417 leerlingen afkomstig zijn van het MDGO. Hoe de schoolverlaters zijn verdeeld over de in het MDGO onderscheiden richtingen is in tabel 1 te zien.

Tabel 1. Aantallen en percentages schoolverlaters per opleidingsrichting

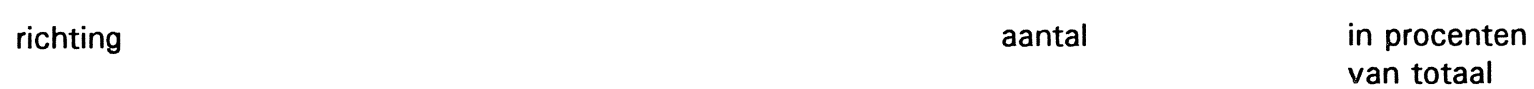

$\begin{array}{lrr}\text { Verzorging } & 1511 & 20 \\ \text { Sociale arbeid } & 140 & 2 \\ \text { Agogisch werk } & 1588 & 21 \\ \text { Assistenten gezondheidszorg } & 890 & 12 \\ \text { Civiele \& cons-techn diensten } & 343 & 5 \\ \text { Mode en kleding } & 944 & 13 \\ \text { Activiteitenbegeleiding } & 343 & 5 \\ \text { Sport en beweging } & 82 & 1 \\ \text { Uiterlijke verzorging } & 209 & 3 \\ \text { Verpleging } & 23 & 0 \\ \text { Overige gediplomeerden } & 42 & 1 \\ \text { Totaal gediplomeerden } & 6115 & 82 \\ \text { Ongediplomeerden } & 1302 & 18 \\ \text { Totaal } & 7417 & 100\end{array}$

De categorie 'overige gediplomeerden' uit tabel 1 geeft de schoolverlaters weer die niet bij een van bovengenoemde richtingen konden worden ingedeeld. Het betreft hier slechts 42 schoolverlaters. Deze groep individuen zal bij de bespreking van de in deze studie 
$-6-$

gepresenteerde resultaten buiten beschouwing blijven. Uit de tabel kan worden afgelezen dat met name de richtingen verzorging, agogisch werk, assistenten gezondheidszorg en mode en kleding goed zijn vertegenwoordigd in de MDGO-populatie. Daarentegen zitten er minder schoolverlaters uit de richtingen sport en beweging, uiterlijke verzorging en verpleging in het RUBS-gegevensbestand.

De voortijdige schoolverlaters zullen in deze studie niet naar richting worden verbijzonderd. Dit gebeurt niet alleen omdat de aantallen bij een opsplitsing al snel erg klein worden, maar ook omdat het minder zinvol lijkt de bestemming van schoolverlaters te relateren aan een opleiding die zij niet hebben afgemaakt en waarvan de opleidingsdoelstellingen dus niet volledig kunnen zijn gerealiseerd (Van Laarhoven en Waslander, 1990).

De centrale vraag in de RUBS-enquête is wat de voornaamste bezigheid is van de degenen die uit een bepaald opleidingstype zijn gestroomd. Het doel van deze vraag is, na te gaan in hoeverre de opleidingen erin slagen hun leerlingen voldoende kwalificaties mee te geven voor een succesvolle vervolgloopbaan. Hierbij moet wel worden bedacht dat de tijd tussen afstuderen en enquêteren wellicht te kort is, om eenduidige uitspraken te kunnen doen over de arbeidsmarktpositie op langere termijn van degenen die werk zijn gaan zoeken.

In tabel 2 staat aangegeven wat de schoolverlaters, gesplitst naar schoolverlaters met en zonder diploma, na het verlaten van het MDGO zijn gaan doen. Ongeveer $80 \%$ van de gediplomeerde schoolverlaters blijkt na één jaar de arbeidsmarkt te hebben betreden. Gemiddeld heeft $64 \%$ een baan gevonden en was $4 \%$ op het tijdstip van de enquête werkloos. Verder is $15 \%$ naar een voltijd dagopleiding gegaan en nog eens $12 \%$ is doorgestroomd naar een deeltijd opleiding (in-service opleiding of een opleiding in het leerlingwezen). Het verschil in de werkloosheidspercentages tussen voortijdige en gediplomeerde schoolverlaters is gering. Voor de gediplomeerde schoolverlaters geldt een werkloosheidspercentage van $4 \%$; van de ongediplomeerden is $6 \%$ werkloos. Ten opzichte van de schoolverlaters zonder diploma heeft echter wel een hoger percentage diplomabezitters een baan (respectievelijk $48 \%$ ten opzichte van $64 \%)$. De schoolverlaters zonder diploma daarentegen volgen vaker een dagopleiding, een in-service opleiding of een opleiding in het leerlingwezen (LLW).

Op basis van de RUBS-gegevens kan niet worden geconcludeerd dat de voortijdige schoolverlaters in een slechtere arbeidsmarktpositie terecht komen dan de gediplomeerde MDGO-ers. Bijna $40 \%$ van de ongediplomeerden zet zijn opleidingstraject voort, hetzij in een andere vorm van voltijd onderwijs, hetzij in het deeltijd onderwijs in de vorm van een in-service opleiding of het leerlingwezen. Ook bij degenen die na het afbreken van hun opleiding op de 
arbeidsmarkt terecht komen is het risico van een zwakkere arbeidsmarktpositie aanwezig. Dit wordt echter eveneens niet door de RUBS-data aangetoond. Hierbij moet worden bedacht dat, zoals al is opgemerkt, de periode tussen het verlaten van het onderwijs en het moment van enquêteren te kort is om hierover definitieve uitspraken te kunnen doen. Het is mogelijk dat de arbeidsmarktpositie van ongediplomeerde schoolverlaters op langere termijn verslechtert ten opzichte van de arbeidsmarktpositie van gediplomeerde MDGO-ers.

Tabel 2. Bestemming van de MDGO-schoolverlaters in procenten per opleidingsrichting

\begin{tabular}{|c|c|c|c|c|c|}
\hline richting & $\begin{array}{c}\text { werk } \\
\%\end{array}$ & $\begin{array}{l}\text { LLW/in- } \\
\text { service } \\
\%\end{array}$ & $\begin{array}{l}\text { werkloos } \\
\%\end{array}$ & $\begin{array}{l}\text { dagop- } \\
\text { leiding } \\
\%\end{array}$ & $\begin{array}{c}\text { overig } \\
\%\end{array}$ \\
\hline Verzorging & 75 & 19 & 1 & 3 & 2 \\
\hline Sociale arbeid & 39 & 5 & 9 & 44 & 4 \\
\hline Agogisch werk & 42 & 20 & 5 & 26 & 7 \\
\hline Assistenten gezondheidszorg & 87 & 5 & 2 & 5 & 1 \\
\hline Civiele \& cons-techn. diensten & 60 & 3 & 3 & 19 & 15 \\
\hline Mode en kleding & 64 & 4 & 7 & 19 & 5 \\
\hline Activiteitenbegeleiding & 61 & 9 & 5 & 20 & 6 \\
\hline Sport en beweging & 62 & 4 & 6 & 16 & 12 \\
\hline Uiterlijke verzorging & 82 & 5 & 5 & 3 & 5 \\
\hline Verpleging & 39 & 9 & 0 & 39 & 13 \\
\hline Overige gediplomeerden & 39 & 29 & 0 & 22 & 10 \\
\hline Totaal gediplomeerden & 64 & 12 & 4 & 15 & 5 \\
\hline Ongediplomeerden & 48 & 19 & 6 & 20 & 8 \\
\hline Totaal & 61 & 13 & 4 & 16 & 6 \\
\hline
\end{tabular}

De verschillen per opleidingsrichting met betrekking tot de bestemming van de MDGOschoolverlaters staan ook aangegeven in tabel 2. Het verschil in arbeidsmarktintrede (dat is werken, werkloos zijn en werken gecombineerd met leren in een in-service opleiding of in het leerlingstelsel) is voor de onderscheiden opleidingsrichtingen nogal groot. Voor verzorging, assistenten gezondheidszorg en uiterlijke verzorging geldt een arbeidsmarktintrede van meer dan $90 \%$. In de richtingen sociale arbeid en verpleging daarentegen bedraagt de arbeidsmarktintrede ongeveer $50 \%$. Uit tabel 2 is het omgekeerde beeld af te leiden voor het voltijd verder leren. Voor de overige richtingen ligt de arbeidsmarktintrede ongeveer op $70 \%$ en stroomt circa $30 \%$ naar een voltijd dagopleiding door. Met name in de richtingen verzorging en agogisch werk komt de combinatie van werken en leren relatief vaak voor. Het betreft hier voornamelijk in-service opleidingen. Relatief veel schoolverlaters uit de richtingen civiele en consumptieve-technische diensten behoren tot de categorie 'overig'. Dit heeft waarschijnlijk te maken met de militaire dienstplicht van het grotere aantal mannen die in deze richtingen uitstroomt. 


\section{WERKLOOSHEID EN WERKZEKERHEID VAN MDGO-ERS}

\subsection{Werkloosheid onder MDGO-ers}

In dit hoofdstuk staat de kans op werk centraal. Er wordt ingegaan op de werkloosheid onder de MDGO-schoolverlaters en op de mate van werkzekerheid van de opleidingsrichtingen. In deze paragraaf zal als eerste worden ingegaan op de werkloosheid onder de MDGO-schoolverlaters. Uit tabel 2 kan het werkloosheidspercentage worden berekend. Daarbij moet rekening worden gehouden met een mogelijke onderschatting van de werkloosheid, omdat de respons van werkloze schoolverlaters misschien lager is. Zoals in paragraaf 2.2 reeds is aangegeven heeft het door een aantal COA's uitgevoerde non-responsonderzoek echter geen aanleiding gegeven tot de conclusie dat de non-respons selectief van aard is. Derhalve zal hier verder geen aandacht aan worden geschonken.

Voordat de werkloosheidspercentages worden besproken moet het volgende worden opgemerkt. De in deze studie bepaalde werkloosheidscijfers wijken af van de geregistreerde werkloosheidscijfers. De hier gehanteerde definitie van werkloosheid komt het meeste overeen met de definitie zoals die door de International Labor Organization (ILO) wordt geformuleerd (zie Ministerie van Sociale Zaken en Werkgelegenheid, 1989) ${ }^{1}$.

Schema 1. Typering van arbeidsmarktsituatie

\begin{tabular}{cl}
\hline werkloosheidspercentage & typering \\
& \\
$0 \%<W \leq 4 \%$ & groot tekort \\
$4 \%<W \leq 6 \%$ & tekort \\
$6 \%<W \leq 8 \%$ & evenwicht \\
$8 \%<W \leq 11 \%$ & overschot \\
$11 \%<W$ & groot overschot \\
\hline
\end{tabular}

Bron: Van Paridon $(1990)^{2}$.

Op basis van de werkloosheidspercentages komt Van Paridon tot een typering van de arbeidsmarktsituatie met betrekking tot de onderscheiden opleidingsrichtingen. Een centraal element in de typering van Van Paridon is de frictiewerkloosheid (Van Paridon, 1987). Indien de werkloosheid gelijk is aan de frictiewerkloosheid is er sprake van evenwicht op de arbeidsmarkt.

1. Het geregistreerde werkloosheidscijfer is in principe wel te bepalen, maar dit is tamelijk bewerkelijk.

2. Deze grenzenindeling is afkomstig uit correspondentie met Van Paridon. 
Uit analyses van het Centraal Planbureau (CPB) blijkt dat de frictiewerkloosheid in Nederland de afgelopen jaren is gestegen. Afhankelijk van de berekeningswijze bedraagt de frictiewerkloosheid tussen de $3,5 \%$ en $5 \%$ (zie Centraal Economisch Plan 1988). Het werkloosheidspercentage waarbij de arbeidsmarkt voor het schoolverlaterssegment in evenwicht is, wordt door Van Paridon op basis hiervan op $7 \%$ gesteld, er van uitgaande dat de arbeidsmobiliteit en derhalve ook de frictiewerkloosheid onder jongeren relatief hoog is.

$\mathrm{Na}$ het verlaten van het MDGO is $80 \%$ van de diplomabezitters en $73 \%$ van de voortijdige schoolverlaters een baan gaan zoeken ${ }^{3}$, dit komt overeen met respectievelijk 4872 en 939 personen. In tabel 3 staan achtereenvolgens, het aantal schoolverlaters per MDGO-richting dat een baan is gaan zoeken ( $n$ ), het percentage schoolverlaters dat in de betreffende richting werkloos (W) is en de typering van de arbeidsmarktsituatie volgens Van Paridon (schema 1).

Uit tabel 3 kan worden afgeleid dat er op de arbeidsmarkt een overschot aan schoolverlaters voorkomt in de richtingen mode en kleding, sport en beweging en sociale arbeid. Voor laatstgenoemde richting is er zelfs sprake van een groot overschot op de arbeidsmarkt. Grote tekorten aan schoolverlaters treden op voor diplomabezitters afkomstig uit verzorging, assistenten gezondheidszorg en civiel \& consumptief-technische diensten. In de richting verpleging komen geen werklozen voor. Hierbij moet echter worden bedacht dat het aantal leerlingen in deze richting dat na het MDGO een baan is gaan zoeken erg gering is. Verder is er een tekort aan mensen met diploma van activiteitenbegeleiding en uiterlijke verzorging. De arbeidsmarkt voor de diplomabezitters van agogisch werk is in evenwicht. Overigens bedraagt het werkloosheidspercentage van alle gediplomeerde MDGO-schoolverlaters $5 \%$, dat wil zeggen dat voor de diplomabezitters als gehele groep een tekort optreedt op de arbeidsmarkt. Voor de voortijdige schoolverlaters geldt een werkloosheidspercentage van $8 \%$. Dit houdt in dat de arbeidsmarkt voor ongediplomeerden zich, volgens de typering van Van Paridon, in een evenwichtssituatie bevindt.

Om na te gaan of de afkomst van een bepaalde opleidingsrichting en het in bezit zijn van het diploma van invloed zijn op de werkloosheidspercentages is de Cramer's $V$ bepaald. Indien de Cramer's $V$ gelijk is aan 0 bestaat er geen relatie tussen het werkloosheidspercentage enerzijds en de opleidingsrichting of het diplomabezit anderzijds; als de Cramer's $\mathrm{V}$ de waarde 1 aanneemt is sprake van een perfecte relatie. Op basis hiervan kan worden geconcludeerd dat het diplomabezit niet of nauwelijks invloed heeft op de werkloosheidspercentages. De opleidingsrichtingen daarentegen spelen een belangrijkere rol.

3. De schoolverlaters die naast een opleiding in het leerlingwezen of een in-service opleiding werk zijn gaan zoeken worden hierbij ook meegenomen. 
Tabel 3. Werkloosheidspercentages en typeringen naar MDGO-richting

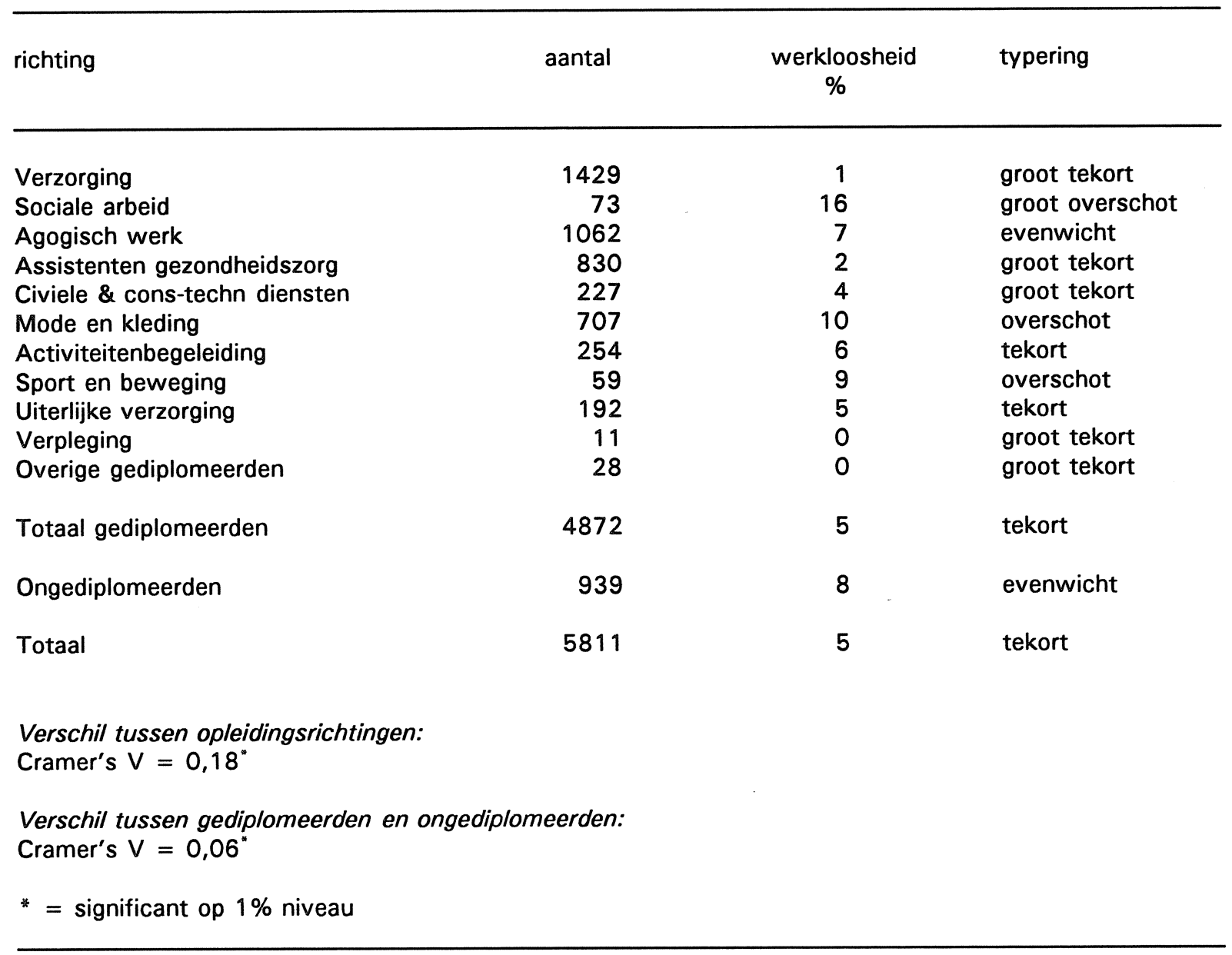

In tabel 4 worden de werkloosheidspercentages van de Randstad ten opzichte van de werkloosheidspercentages van de rest van Nederland gepresenteerd. Er is hier slechts gekozen voor een tweedeling, vanwege de geringe aantallen schoolverlaters per regio en per opleidingsrichting die zouden resulteren indien een minder geaggregeerde indeling zou worden gehanteerd. Het zou in dat geval niet mogelijk zijn enige conclusies te verbinden aan de berekende werkloosheidspercentages ${ }^{4}$. De twee onderscheiden regio's zijn als volgt ingedeeld:

Randstad = Utrecht, Noord-Holland en Zuid-Holland;

Rest van Nederland = Groningen, Friesland, Drenthe, Overijssel, Gelderland, Zeeland en Flevoland.

Voor de gediplomeerde schoolverlaters uit de Randstad geldt een werkloosheidspercentage van 4\%. Dit duidt op een krappe arbeidsmarkt voor gediplomeerde MDGO-ers in de Randstad. Tabel 4 laat zien dat in de rest van Nederland het werkloosheidspercentage van gediplomeerde

4. Bij een grootschalige voortzetting van het RUBS-project zou een veel verdergaande verbijzondering naar regio mogelijk zijn. 
MDGO-ers $6 \%$ bedraagt. Ook hier treedt er een tekort op aan diplomabezitters. Er komen aanzienlijke verschillen voor in de werkloosheidspercentages voor beide onderscheiden regio's. In de Randstad treedt voor 6 van 10 opleidingsrichtingen een groot tekort op. Slechts in én opleidingsrichting is er sprake van een overschot, namelijk in de richting sociale arbeid. In de rest van Nederland daarentegen worden slechts drie richtingen gekenmerkt door een groot tekort of een tekort op de arbeidsmarkt, terwijl er vijf opleidingsrichtingen met een overschot voorkomen. De arbeidsmarkt voor voortijdige schoolverlaters is daarentegen in evenwicht. Het werkloosheidspercentage van ongediplomeerden bedraagt voor zowel de Randstad als de rest van Nederland $8 \%$.

Tabel 4. Werkloosheidspercentages voor de MDGO-richtingen per onderscheiden regio

\begin{tabular}{|c|c|c|c|c|c|c|}
\hline \multirow[t]{2}{*}{ richting } & \multicolumn{3}{|c|}{ Randstad } & \multicolumn{3}{|c|}{ Rest } \\
\hline & aantal & $\%$ & typering & aantal & $\%$ & typering \\
\hline Verzorging & 784 & 1 & groot tekort & 644 & 0 & groot tekort \\
\hline Sociale arbeid & 47 & 11 & overschot & 26 & 27 & groot overschot \\
\hline Agogisch werk & 605 & 6 & tekort & 457 & 9 & overschot \\
\hline Assistenten gezondheidszorg & 450 & 1 & groot tekort & 380 & 3 & groot tekort \\
\hline Civiele \& cons-techn diensten & 97 & 1 & groot tekort & 130 & 6 & tekort \\
\hline Mode en kleding & 463 & 8 & evenwicht & 244 & 13 & groot overschot \\
\hline Activiteitenbegeleiding & 152 & 5 & tekort & 102 & 8 & evenwicht \\
\hline Sport en beweging & 17 & 0 & groot tekort & 42 & 12 & groot overschot \\
\hline Uiterlijke verzorging & 144 & 3 & groot tekort & 48 & 10 & overschot \\
\hline Verpleging & 11 & 0 & groot tekort & - & - & n.v.t. \\
\hline Overige gediplomeerden & - & - & n.v.t. & 28 & 0 & groot tekort \\
\hline Totaal gediplomeerden & 2770 & 4 & groot tekort & 2101 & 6 & tekort \\
\hline Ongediplomeerden & 587 & 8 & evenwicht & 352 & 8 & evenwicht \\
\hline Totaal & 3357 & 4 & groot tekort & 2453 & 6 & tekort \\
\hline
\end{tabular}

Hierbij moet overigens worden bedacht dat de conclusies voor een aantal richtingen niet significant zijn, gezien het geringe aantal leerlingen in de desbetreffende richtingen dat na het MDGO een baan is gaan zoeken. Voor de Randstad geldt dat de aantallen schoolverlaters in de richtingen sociale arbeid, sport en beweging en verpleging klein zijn, het betreft hier respectievelijk 47, 17 en 11 schoolverlaters. In de rest van Nederland geldt dat in de richtingen sociale arbeid, sport en beweging en uiterlijke verzorging sprake is van kleine aantallen. Het gaat hier om respectievelijk 26, 42 en 48 schoolverlaters. Er moet derhalve bij deze richting weinig betekenis worden gehecht aan de bij deze percentages behorende typeringen.

Om na te gaan of met betrekking tot de werkloosheidspercentages het er toe doet of de schoolverlater in de Randstad woont of in de rest van Nederland is weer de Cramer's V bepaald. 
Daaruit blijkt dat slechts voor de totale groep aan gediplomeerde MDGO-schoolverlaters de berekende Cramer's V significant is. Voor de afzonderlijke opleidingsrichtingen bestaat geen relatie tussen de regio waar de schoolverlater woont en het werkloosheidspercentage.

\subsection{Mate van werkzekerheid voor MDGO-ers}

In de vorige paragraaf is op basis van het werkloosheidspercentage een typering van de actuele arbeidsmarktsituatie gegeven. Hierbij is echter buiten beschouwing gebleven of deze arbeidsmarktsituatie van tijdelijke of van meer permanente aard is. In deze paragraaf zal derhalve de conjunctuurgevoeligheid, ofwel de mate van werkzekerheid, van de afzonderlijke opleidingsrichtingen aan de orde komen.

In de afzonderlijke bedrijfssectoren is de reactie van de werkgelegenheid op conjunctuurschommelingen in het verleden nogal verschillend geweest. Om dit na te gaan is een fluctuatie-index geconstrueerd. Deze index wordt uitgedrukt als het quotiënt van de afwijking van de trendmatige werkgelegenheidsontwikkeling van een bepaalde bedrijfssector in een bepaald jaar en de trendmatige werkgelegenheidsontwikkeling van de desbetreffende bedrijfssector:

$$
F I_{j}=\frac{100}{H} \sum_{t=1}^{H} \frac{\left|F_{j t}\right|}{T_{j t}}
$$

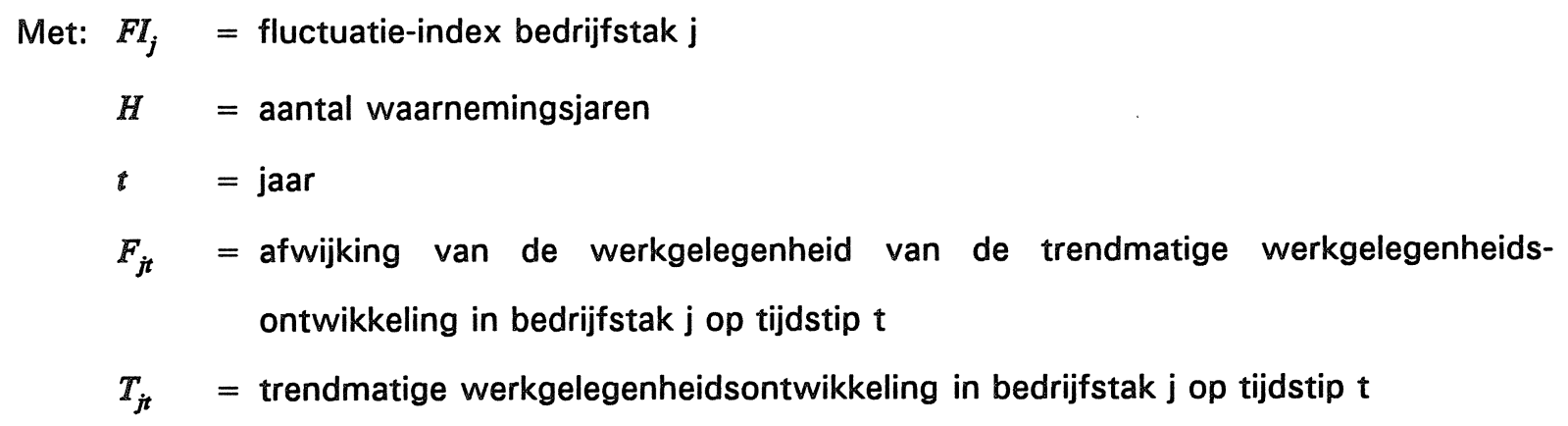

Vervolgens kan uit deze fluctuatie-index van de onderscheiden bedrijfstakken een fluctuatieindex voor de verschillende opleidingsrichtingen worden afgeleid. Op basis van de veronderstelling dat de werkgelegenheid van de verschillende opleidingsrichtingen binnen een bedrijfstak in gelijk mate fluctueert, wordt de index voor elke opleidingsrichting bepaald door de indices van de sectoren te wegen met de aandelen van de sectoren in de totale werkgelegenheid van de desbetreffende opleidingsrichting (zie De Grip en Heijke, 1988 en De Grip, Heijke en Dekker, 1989): 


$$
C G_{k}=\sum_{j=1}^{J} \beta_{k j} F I_{j}
$$

Met: $C G_{k}=$ indicator conjunctuurgevoeligheid opleiding $\mathrm{k}$

$\boldsymbol{\beta}_{k j} \quad=$ aandeel opleiding $\mathrm{k}$ werkzaam in bedrijfstak $\mathrm{j}$

De conjunctuurindicator is van belang bij het beoordelen van de actuele en/of voorspelde arbeidsmarktpositie van de schoolverlaters in de verschillende opleidingsrichtingen. In het geval er namelijk sprake is van tekorten of overschotten op de arbeidsmarkt bij sterk conjunctuurgevoelige opleidingsrichtingen moet er rekening worden gehouden met het mogelijk tijdelijke karakter van deze onevenwichtigheden. Een nadeel van deze conjunctuurindicator is, dat moet worden uitgegaan van de veronderstelling van gelijkmatig verlopende conjunctuurschommelingen voor de diverse opleidingscategorieën binnen een bedrijfstak.

De kwalitatieve typering van de resultaten van de conjunctuurindicator is gebaseerd op een grenzenindeling die is bepaald op basis van de voor het informatiesysteem I-See! berekende conjunctuurgevoeligheid van de opleidingen (zie ook Wieling, De Grip en Willems, 1990). Dit maakt het mogelijk uitspraken te doen over de mate van conjunctuurgevoeligheid van de werkgelegenheid in een bepaalde MDGO-opleidingsrichting, in vergelijking met alle andere opleidingstypen ${ }^{5}$. Dit heeft tot gevolg dat de onderstaande grenzenindeling wordt gehanteerd:

Schema 2. Typering van de conjunctuurindicator

de conjunctuurindicator

$C G \leq 1,15$
$1,15<C G \leq 1,35$
$1,35<C G \leq 1,60$
$1,60<C G \leq 1,80$
$1,80<C G$

typering

relatief erg klein

relatief klein

gemiddeld

relatief groot

relatief erg groot

Uit tabel 5 blijkt dat de conjunctuurgevoeligheid in vrijwel alle richtingen op een gemiddeld niveau ligt. Uitzonderingen hierop zijn de richtingen mode en kleding die wordt gekenmerkt door een relatief hoge conjunctuurgevoeligheid en de richting uiterlijke verzorging waarin sprake is

5. De conjunctuurindicator is afgeleid uit de fluctuatie-index, die de in het verleden opgetreden conjunctuurschommelingen in de afzonderlijke bedrijfssectoren weergeeft. Het verschil in aggregatie-niveau van de hier onderscheiden opleidingsrichtingen met de opleidingsindeling in het ROA/I-See! informatiesysteem speelt hier derhalve geen grote rol. 
van een kleine conjunctuurgevoeligheid. Met andere woorden bestaat de mogelijkheid dat het overschot dat in de richting mode en kleding optreedt tijdelijk is. Daarentegen geeft de conjunctuurindicator aan dat het tekort aan MDGO-ers van de richting uiterlijke verzorging waarschijnlijk niet gemakkelijk als gevolg van conjuncturele fluctuaties zullen verdwijnen.

Tabel 5. De conjunctuurgevoeligheid van opleidingsrichtingen

\begin{tabular}{lll}
\hline richting & CG & typering \\
\hline & & \\
Verzorging & 1,55 & gemiddeld \\
Sociale arbeid & 1,43 & gemiddeld \\
Agogisch werk & 1,56 & gemiddeld \\
Assistenten gezondheidszorg & 1,57 & gemiddeld \\
Civiel \& cons-techn diensten & 1,52 & gemiddeld \\
Mode en kleding & 1,71 & relatief groot \\
Activiteitenbegeleiding & 1,60 & gemiddeld \\
Sport en beweging & 1,43 & gemiddeld \\
Uiterlijk verzorging & 1,35 & relatief klein \\
Verpleging & 1,59 & gemiddeld \\
Overige gediplomeerden & 1,42 & gemiddeld \\
Totaal gediplomeerden & 1,57 & gemiddeld \\
Ongediplomeerden & 1,55 & gemiddeld \\
\hline Totaal & 1,57 &
\end{tabular}




\section{FUNCTIENIVEAU EN INKOMEN VAN DE WERKENDE MDGO-ERS}

\subsection{Functieniveau van de werkende MDGO-ers}

In dit hoofdstuk wordt nader ingegaan op indicatoren die iets zeggen over de aard van het werk van de werkende schoolverlaters. Allereerst komt het functieniveau behorend bij het beroep dat door de schoolverlaters wordt uitgeoefend aan de orde. Vervolgens wordt in de volgende paragraaf het inkomen dat door de schoolverlaters wordt verdiend besproken.

Om een eerste indicatie te krijgen van de functieniveaus van de werkende MDGO-ers, is het gemiddelde functieniveau per opleiding bepaald. Dit wordt gepresenteerd in tabel 6. Met betrekking tot de functieniveaus is er gebruik gemaakt van de functieniveaus die door Huijgen (1989) aan de beroepen (volgens CBS-beroepenclassificatie op 4-digitniveau) worden toegekend. Het gemiddelde functieniveau voor het gehele MDGO is iets hoger dan 3. Wat opvalt in tabel 6 is dat, zoals verwacht, het gemiddelde functieniveau van schoolverlaters zonder diploma beduidend lager is dan het gemiddelde functieniveau van diplomabezitters voor alle opleidingsrichtingen. De richtingen sport en beweging, activiteitenbegeleiding en assistenten gezondheidszorg onderscheiden zich door relatief hoge functieniveaus lafgerond betekent dit functieniveaus van 4 of hoger). Daarentegen hebben de richtingen civiele \& consumptieftechnische diensten en mode en kleding een relatief laag functieniveau (lager dan 3 ).

Het gemiddelde functieniveau zegt echter niets over de spreiding van de werkenden afkomstig van een bepaalde opleidingsrichting over de functieniveaus. Derhalve is naast het gemiddelde functieniveau ook de standaarddeviatie van het functieniveau bepaald. Uit tabel 6 blijkt dat de spreiding in de richtingen civiele \& consumptief-technische diensten, mode en kleding, activiteitenbegeleiding en sport en beweging vrij groot is. Daarentegen kennen de richtingen verzorging en assistenten gezondheidszorg een relatief lage spreiding.

Met betrekking tot het functieniveau is een variantie-analyse toegepast met als verklarende variabelen de onderscheiden opleidingsrichtingen, het al dan niet in het bezit zijn van het diploma en het interactie-effect van opleidingsrichting en het diplomabezit. Uit deze analyse volgt dat zowel de afkomst van een bepaalde MDGO-richting, het diplomabezit en het interactieeffect van beide variabelen een significante invloed hebben op het functieniveau. Uit de berekende eta ${ }^{2}$ kan worden afgeleid dat $21 \%$ van de variantie in het functieniveau wordt verklaard door de afkomst van een bepaalde opleidingsrichting. De effecten van het in het bezit zijn van het diploma en van het interactie-effect tussen opleidingsrichting en diplomabezit zijn daarentegen kleiner. De drie effecten samen verklaren $26 \%$ van de variantie in het functieniveau. 
Tabel 6. Het gemiddelde functieniveau en de spreiding per opleidingsrichting

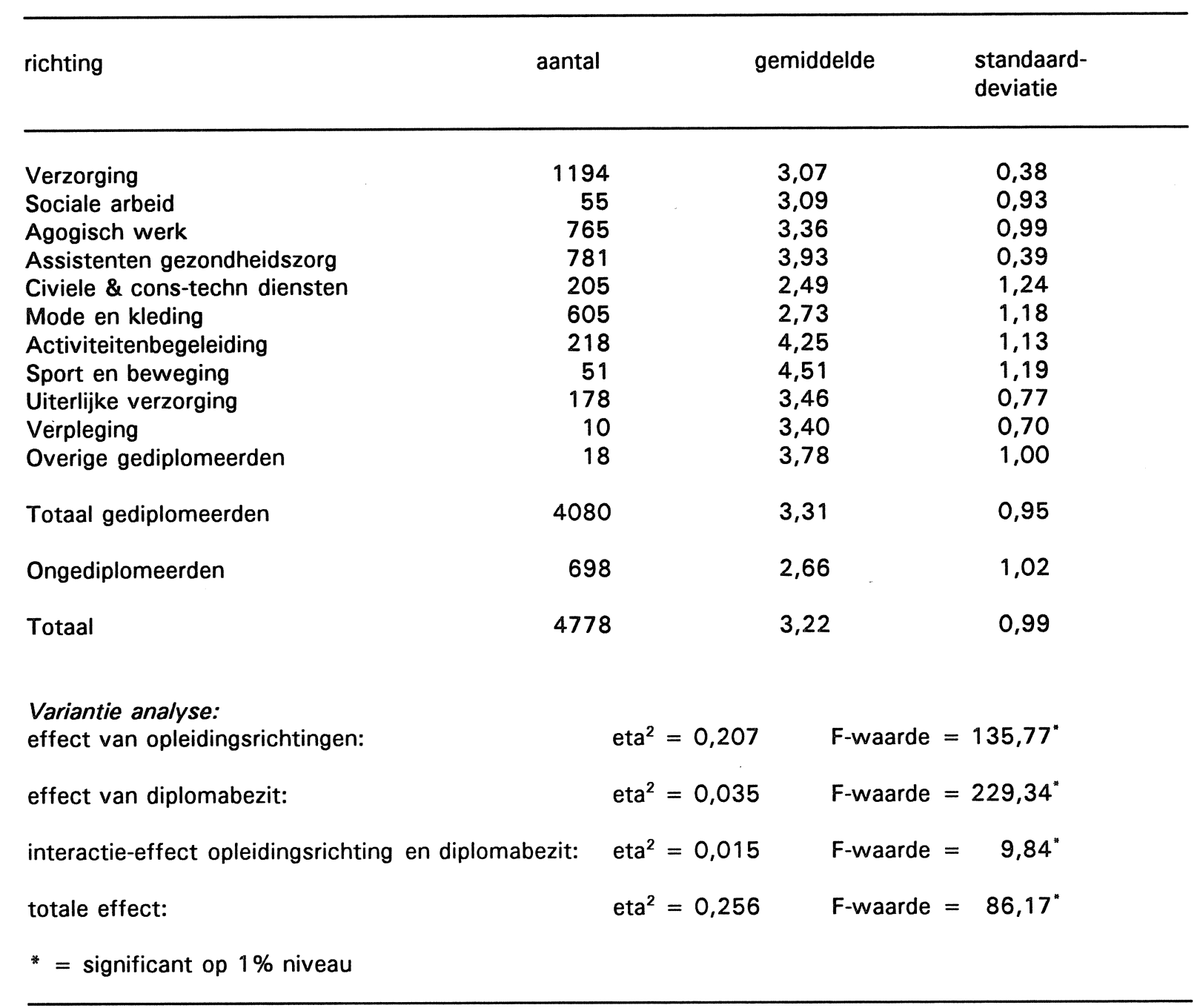

Schema 3. Onder- en overbenuttingsmodel

\begin{tabular}{|c|c|c|}
\hline Opleidingsniveau & $\begin{array}{l}\text { Onderbenutting bi } \\
\text { functieniveau }\end{array}$ & $\begin{array}{l}\text { Overbenutting bij } \\
\text { functieniveau }\end{array}$ \\
\hline
\end{tabular}

$\begin{array}{lll}\text { Basisonderwijs } & & 4,5,6,7 \\ \text { MAVO, LBO } & 1,2 & 5,6,7 \\ \text { HAVO, VWO, MBO } & 1,2,3 & 6,7 \\ \text { HBO } & 1,2,3,4 & 7 \\ \text { WO } & 1,2,3,4,5 & -\end{array}$

Bron: Huijgen (1989).

Naast dit gemiddelde functieniveau per opleidingsrichting is het interessant om te kijken of de baan die de werkende MDGO-ers op het moment van de enquête hadden qua functieniveau aansloot op de gevolgde opleiding. In schema 3 wordt voor de verschillende opleidingsniveaus weergegeven welke functieniveaus voor de schoolverlaters van het MDGO respectievelijk een 
onder- of overbenutting van het kwalificatieniveau van de schoolverlaters impliceren ${ }^{6}$.

In tabel 7 worden de percentages onder- en overbenutting per opleidingsrichting gepresenteerd aan de hand van de functie die door de geënquêteerde schoolverlaters op moment van enquêtering wordt uitgeoefend. Wat betreft schoolverlaters die het MDGO zonder diploma hebben verlaten is het niet duidelijk of de vorige afgemaakte opleiding, ofwel het aantal gevolgde schooljaren op het MDGO bepaalt of er sprake is van over- of onderbenutting. Overen onderbenutting kan daarom slechts eenduidig worden bepaald voor schoolverlaters die het MDGO met diploma hebben verlaten. De totale onderbenutting van de MDGO-schoolverlaters in deze populatie is maar liefst $58 \%$. Indien dit per opleidingsrichting wordt bezien, dan valt op dat de richtingen verzorging, sociale arbeid, civiele \& consumptief-technische diensten, mode en kleding en verpleging zelfs een veel hogere mate van onderbenutting kennen. Daarnaast geldt dat voor agogisch werk en uiterlijke verzorging de onderbenutting ongeveer $45 \%$ bedraagt. Betere aansluiting is te zien bij assistenten gezondheidszorg, activiteitenbegeleiding en sport en beweging.

Tabel 7. Percentages onder- en overbenutting van gediplomeerde MDGO-schoolverlaters

\begin{tabular}{lccc}
\hline richting & $\begin{array}{c}\text { onderbenutting } \\
\%\end{array}$ & $\begin{array}{c}\text { aansluiting } \\
\%\end{array}$ & $\begin{array}{c}\text { overbenutting } \\
\%\end{array}$ \\
\hline Verzorging & 91 & 9 & 0 \\
Sociale arbeid & 78 & 22 & 0 \\
Agogisch werk & 49 & 51 & 1 \\
Assistenten gezondheidszorg & 5 & 95 & 5 \\
Civiele \& cons-techn diensten & 85 & 10 & 4 \\
Mode en kleding & 82 & 14 & 1 \\
Activiteitenbegeleiding & 26 & 74 & 0 \\
Sport en beweging & 16 & 57 & 0 \\
Uiterlijke verzorging & 43 & 30 & 6 \\
Verpleging & 70 & 61 & 1 \\
Overig gediplomeerden & 33 & 41 & 5 \\
Totaal gediplomeerden & 58 & & \\
\hline
\end{tabular}

In figuur 1 worden de werkloosheidspercentages uitgezet tegen de percentages onderbenutting. Op voorhand mag worden verwacht, dat er een positief verband zal bestaan tussen beide percentages. De noodzaak om uit te wijken naar beroepen met een lager functieniveau is immers groter wanneer schoolverlaters geen baan kunnen krijgen die qua functieniveau aansluit

6. In plaats van onderbenutting kan men hier ook spreken van overscholing en in plaats van overbenutting kan worden gesproken van onderscholing. 
op de gevolgde opleiding. Deze verwachting lijkt door de figuur te worden bevestigd. De richtingen assistenten gezondheidszorg, activiteitenbegeleiding, sport en beweging en uiterlijke verzorging vertonen zowel een laag werkloosheidspercentage als een laag percentage van onderbenutting. Daarentegen zijn de percentages voor werkloosheid en onderbenutting hoog voor de opleidingsrichtingen: sociale arbeid en mode en kleding. Uitzonderingen op deze samenhang zijn de richtingen: verzorging en civiele \& consumptief-technische diensten. Deze beide richtingen vertonen een laag werkloosheidspercentage en een hoog percentage van onderbenutting. Dit geeft wellicht aan dat het veel schoolverlaters is gelukt om uit te wijken, maar wel naar een baan met een lager functieniveau. De opleidingsrichting verpleging valt weliswaar eveneens buiten deze positieve samenhang, maar het gaat hier om kleine aantallen en derhalve mag er geen betekenis aan dit percentage worden gehecht.

Figuur 1. Relatie tussen het werkloosheidspercentage en de mate van onderbenutting*

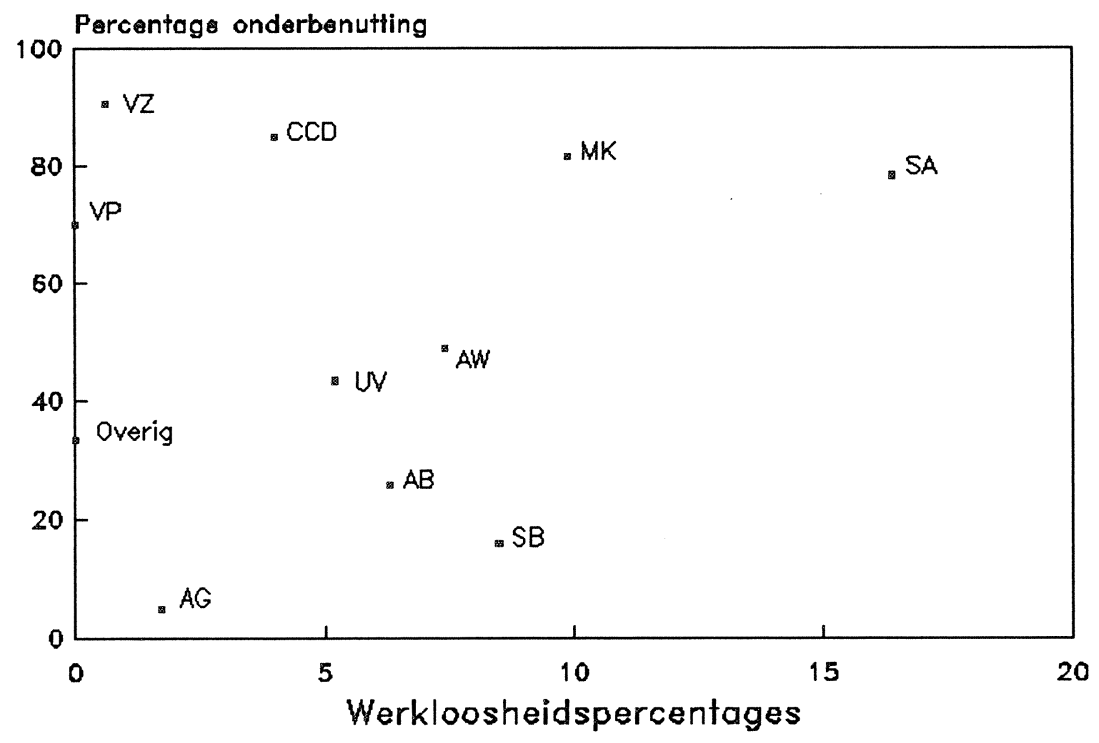

* Zie pagina 5 voor een lijst met afkortingen van de onderscheiden opleidingsrichtingen.

\subsection{Inkomen van de werkende MDGO-ers}

Een factor die vaak met het functieniveau geacht wordt samen te hangen is het inkomen. Dit blijkt hier echter niet het geval te zijn. De correlatie tussen het inkomen en het functieniveau bedraagt slechts 0,22 . Hoewel er in de RUBS-enquête een antwoordmogelijkheid 'zeg ik liever niet' was, is toch door twee derde van de werkende schoolverlaters aangegeven wat zij maandelijks (netto) verdienen. In tabel 8 wordt het gemiddelde netto inkomen per opleidingsrichting gepresenteerd, waarbij de ongediplomeerde schoolverlaters als één groep 
worden beschouwd. Het loon wordt mede bepaald door de leeftijd van de werkende en het aantal uren dat de schoolverlater werkzaam is. Derhalve is naast het gewone gemiddelde loon per opleidingsrichting ook het gecorrigeerde gemiddelde netto maandloon berekend met behulp van multiple classificatie-analyse (MCA). Bij de berekening van dit gecorrigeerde gemiddelde inkomen wordt rekening gehouden met de verschillen in leeftijdsopbouw en de verdeling over full-time en part-time banen tussen de opleidingsrichtingen. Het gevolg van deze correctie is dat de verschillen tussen de opleidingsrichtingen in de meeste gevallen kleiner worden. De rangorde van de opleidingsrichtingen blijft echter door de correctie vrijwel onaangetast.

Tabel 8. Het gemiddelde netto maandloon (in guldens) per opleidingsrichting

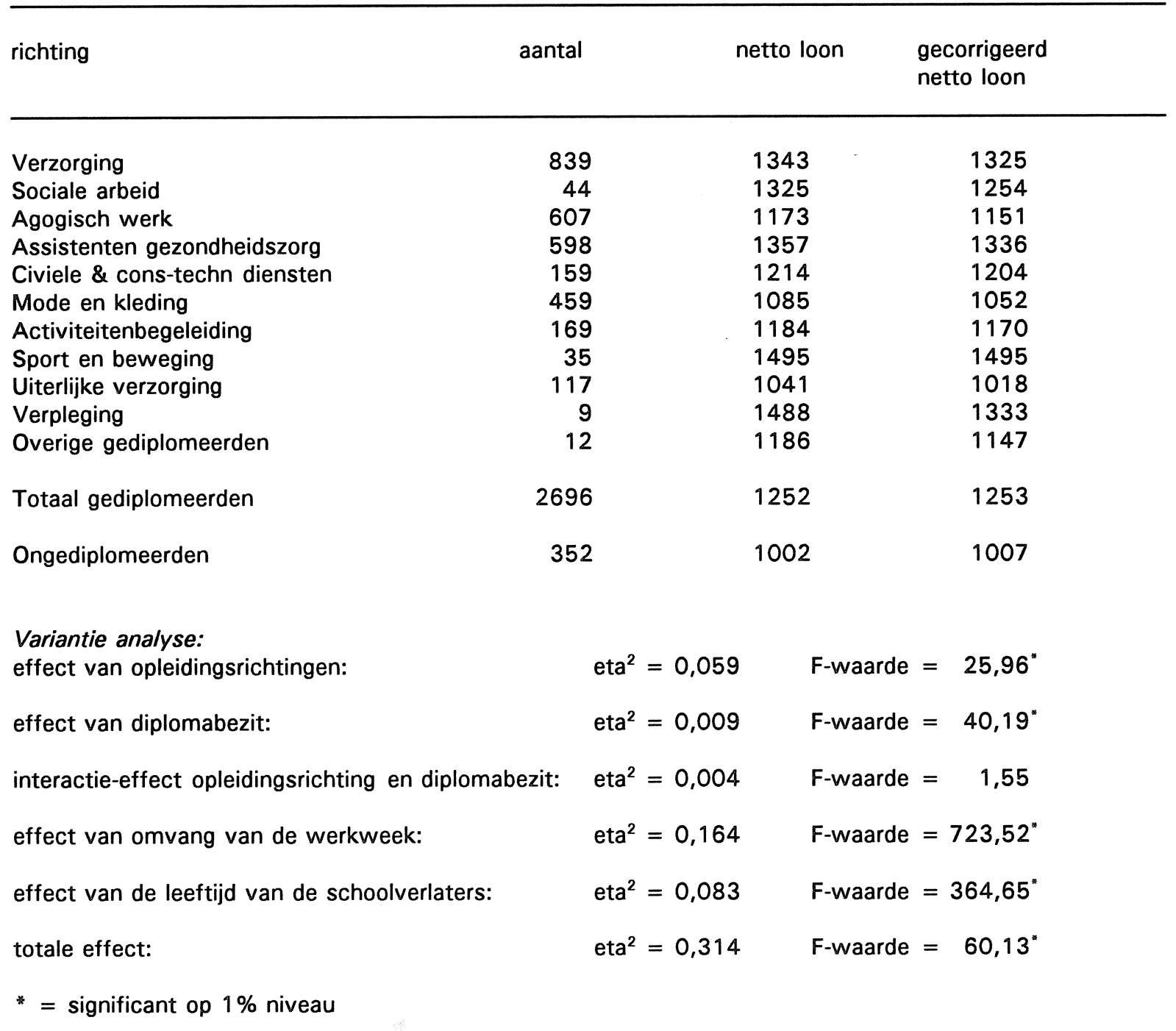

Zoals verwacht is het gemiddelde netto maandloon van de diplomabezitters hoger dan van nietdiplomabezitters. Over alle opleidingsrichtingen bekeken verdienen de schoolverlaters die in het bezit zijn van het diploma (netto) ongeveer 250 gulden per maand meer dan schoolverlaters 
zonder diploma. In de richtingen verzorging, assistenten gezondheidszorg, sport en beweging en verpleging zijn de salarissen vrij hoog (hoger dan 1300 gulden netto per maand). Daarentegen blijkt dat de lonen voor werkenden afkomstig van mode en kleding en uiterlijke verzorging relatief laag zijn.

Bij de interpretatie van deze gemiddelde netto maandlonen moeten een aantal kanttekeningen worden gemaakt. Ten eerste is de correctie niet volledig. Er is bijvoorbeeld geen rekening gehouden met eventuele onregelmatigheidstoeslagen, die in een aantal richtingen veelvuldig voorkomen (Van Laarhoven en Waslander, 1990). Bovendien gaat het om aanvangssalarissen. Zo zou de rangorde na een aantal jaren kunnen veranderen, als de doorgroeimogelijkheden per studierichting verschillen.

Met betrekking tot het netto inkomen is een variantie-analyse toegepast met als verklarende variabelen de onderscheiden opleidingsrichtingen en het wel of niet in het bezit zijn van het diploma. Het aantal uren dat de desbetreffende schoolverlater per week werkt en de leeftijd van de schoolverlaters zijn als covariaten in de variantie-analyse meegenomen. Uit deze analyse volgt dat zowel de afkomst van een bepaalde MDGO-richting, het diplomabezit, het aantal uren werk en de leeftijd een significante invloed hebben op de variantie in het netto maandloon. Uit de berekende eta ${ }^{2}$ kan worden afgeleid dat $16 \%$ van de variantie in het netto maandloon wordt verklaard door het aantal uren dat de schoolverlater per week werkt. De effecten van de afkomst van een bepaalde opleidingsrichting, van het in het bezit zijn van het diploma en van de leeftijd zijn kleiner, namelijk respectievelijk $5,9 \%, 0,9 \%$ en $8,3 \%$. Overigens is het interactieeffect tussen opleidingsrichting en diplomabezit niet significant. Deze vier effecten en het interactie-effect verklaren samen $31 \%$ van de variantie van het gemiddelde functieniveau.

Op basis van het gemiddelde loon kan geen uitspraak worden gedaan over de spreiding van het netto inkomen over de schoolverlaters binnen een bepaalde opleidingsrichting. Om een indicatie te krijgen hoe groot de verschillen in beloning van (full-time) werkenden binnen de onderscheiden richtingen zijn, is als eerste nagegaan hoeveel procent van de schoolverlaters uit de betreffende richting minder verdienen dan respectievelijk $f$ 850,-- (het minimumjeugdloon voor 19-jarigen) en $f$ 975,-- (het minimumjeugdloon voor 20-jarigen). Bovendien is de standaardafwijking van het inkomen in de betreffende opleidingsrichting bepaald.

Uit tabel 9 blijkt dat gemiddeld $5 \%$ van de gediplomeerde schoolverlaters, die full-time werken op het moment van enquêtering, netto minder dan 850 gulden per maand verdienen. Daarbij zijn uitschieters in negatieve zin de richtingen: agogisch werk, mode en kleding en activiteitenbegeleiding. Van alle diplomabezitters verdient $13 \%$ minder dan 975 gulden in de maand. Bij 
deze inkomensgrens scoort ook de richting: uiterlijke verzorging relatief slecht. Uitzonderingen in positieve zin zijn daarentegen de richtingen assistenten gezondheidszorg, sport en beweging en verpleging. Overeenkomstig de verwachting geldt dat van de ongediplomeerde schoolverlaters een relatief grote groep weinig verdient.

Tabel 9. De verschillen in netto maandloon binnen de opleidingsrichtingen

\begin{tabular}{lrccc}
\hline richting & aantal & $\begin{array}{c}\text { minder dan } \\
f 850,-- \\
\%\end{array}$ & $\begin{array}{c}\text { minder dan } \\
f \text { 975,-- } \\
\%\end{array}$ & $\begin{array}{l}\text { standaard- } \\
\text { deviatie }\end{array}$ \\
\hline Verzorging & \multicolumn{5}{c}{$\begin{array}{c}\text { \% } \\
\text { Sociale arbeid }\end{array}$} & 356 & 7 & 264,8 \\
Agogisch werk & 27 & 0 & 4 & 241,2 \\
Assistenten gezondheidszorg & 389 & 10 & 22 & 319,7 \\
Civiele \& cons-techn diensten & 468 & 0 & 2 & 158,8 \\
Mode en kleding & 93 & 3 & 13 & 271,9 \\
Activiteitenbegeleiding & 285 & 11 & 26 & 364,5 \\
Sport en beweging & 83 & 11 & 16 & 322,8 \\
Uiterlijke verzorging & 22 & 0 & 0 & 337,6 \\
Verpleging & 71 & 8 & 27 & 250,2 \\
Overige gediplomeerden & 6 & 0 & 0 & 178,9 \\
Totaal gediplomeerden & 6 & 17 & 17 & 497,5 \\
Ongediplomeerden & 2106 & 5 & 13 & 294,6 \\
Totaal & 279 & 25 & 43 & 340,7 \\
\hline
\end{tabular}

Wat betreft de spreiding van de netto inkomens binnen de onderscheiden opleidingsrichtingen kan het volgende worden opgemerkt. Een relatieve hoge spreiding komt voor bij de richtingen agogisch werk, mode en kleding en activiteitenbegeleiding. Deze richtingen kennen, zoals hierboven reeds werd aangegeven, ook een relatief grote groep werkenden die ten tijde van de enquête een salaris beneden de $f 975,--$ verdienden. De richting sport en beweging kenmerkt zich door een vrij hoge spreiding terwijl geen van de werkenden minder dan 975 gulden per maand verdient. Daarentegen is in de richtingen verpleging en assistenten gezondheidszorg de spreiding relatief gering. Deze richtingen worden gekenmerkt door een relatief kleine groep schoolverlaters met een netto maandloon van minder dan $f$ 975,--. 


\section{FLEXIBILITEITSINDICATOREN}

\subsection{Gini-Hirschman coëfficiënt}

Aan de hand van de RUBS-gegevens is ook een aantal spreidingsindicatoren met betrekking tot de branche- en beroepenspreiding en opleidingspreiding van beroepen van de 10 MDGOrichtingen bepaald. Voordat de resultaten worden besproken zal eerst nader worden ingegaan op de Gini-Hirschman coëfficiënt.

De opvatting dat er een directe en exclusieve relatie bestaat tussen opleidingen en beroepen wordt door Van Hoof en Dronkers bekritiseerd (1980). Dit naïeve model van de arbeidsmarkt negeert ten onrechte de bestaande flexibiliteit in aansluiting van opleidingen en beroepen. Schoolverlaters met een bepaalde opleiding kunnen in geheel verschillende beroepen terecht komen en veel beroepen worden uitgeoefend door afgestudeerden met een geheel verschillende opleidingsachtergrond. Het naïeve model impliceert dat een betere aansluiting tussen onderwijs en arbeidsmarkt kan worden bewerkstelligd door de scholing van het arbeidsaanbod perfect te laten aansluiten op de op de arbeidsmarkt gevraagde kwalificaties. Volgens het flexibiliteitsmodel dat Van Hoof en Dronkers naar voren brengen is veeleer een verbreding van het kwalificatieprofiel van de schoolverlaters het aangewezen middel om aansluiting tussen onderwijs en arbeidsmarkt te verbeteren. In dat geval is het van groot belang om een indicatie te hebben van de bestaande flexibiliteit van schoolverlaters.

Een maatstaf die een indicatie geeft van de bestaande flexibiliteit op de arbeidsmarkt is de GiniHirschman coëfficiënt (GH) (Sheldon, 1985 en Warnken, 1986). Op basis van deze maatstaf kunnen de branchespreiding en de beroepenspreiding van de verschillende opleidingscategorieën worden bepaald. Het grote voordeel van deze indicator is, dat hij zeer makkelijk is te interpreteren. De indicator neemt waarden aan tussen 0 en 1 . De branchespreiding van opleidingen is 0 als de opleidingsrichting slechts in één branche voorkomt en 1 als de opleidingsrichting gelijkmatig over alle branches is verspreid. Hetzelfde geldt voor de beroepenspreiding van opleidingen. Deze is 0 als de opleidingsrichting slechts in én beroep voorkomt en 1 als de opleidingsrichting over alle beroepen is verspreid. De situaties van een exclusieve relatie tussen opleidingen en beroepen (coëfficiënt is 0 ) en van volledige flexibiliteit (coëfficiënt is 1) kunnen worden gezien als twee ideaaltypische extremen. Waarschijnlijker is echter dat de meeste beroepen en opleidingen zich ver van beide extremen bevinden. Meestal kan met een bepaalde opleiding een beperkt aantal beroepen worden uitgeoefend (zie De Grip en Heijke, 1989). 
Overigens moet worden opgemerkt dat de hier weergegeven spreidingsindicatoren niet betrekking hebben op de potentiële flexibiliteit, maar op de feitelijk opgetreden flexibiliteit van de gediplomeerde schoolverlaters.

Voor de typering van de mate van arbeidsmarktflexibiliteit is in het verleden gebruik gemaakt van een enigszins arbitraire indeling van de Gini-Hirschman coëfficiënt (zie bijvoorbeeld De Grip en Heijke, 1988). Deze indeling luidt als volgt:

Schema 4. Typering van de spreidingsindicatoren

Gini-Hirschman coëfficiënt

$$
\begin{aligned}
\mathrm{GH} & =0,0 \\
0,0<\mathrm{GH} & \leq 0,3 \\
0,3<\mathrm{GH} & \leq 0,7 \\
0,7<\mathrm{GH} & \leq 1,0 \\
\mathrm{GH} & =1,0
\end{aligned}
$$

typering arbeidsmarktinformatie

geen enkele spreiding/flexibiliteit/uitwijkmogelijkheden (het ideaaltypische naïeve model)

geringe spreiding/flexibiliteit; weinig uitwijkmogelijkheden gemiddelde spreiding; enige flexibiliteit/uitwijkmogelijkheden grote spreiding/flexibiliteit; veel uitwijkmogelijkheden

geheel gelijkmatige spreiding; algehele flexibiliteit; onbeperkte uitwijkmogelijkheden (het ideaaltypische flexibiliteitsmodel)

Bron: De Grip en Heijke (1988).

Een nadeel van deze arbitraire indeling is dat niet na kan worden gegaan of er inderdaad sprake is van een gemiddelde spreiding indien de waarde van de indicator tussen de 0,3 en 0,7 ligt. In zijn algemeenheid kan worden opgemerkt dat de coëfficiënten de neiging hebben om snel te stijgen, hetgeen de typering vaak op een gemiddelde of grote spreiding doet uitkomen. Om dit op te lossen wordt van de bovenstaande indeling afgeweken. De kwalitatieve typeringen van de berekende resultaten van de spreidingsindicatoren zijn gebaseerd op een grenzenindeling die relatief is gemaakt aan de uitkomsten van de overige MDGO-opleidingsrichtingen. Dat wil zeggen dat de typering wordt bepaald met behulp van het gemiddelde $(\mu)$ van de Gini-Hirschman coëfficiënten en de standaarddeviatie $(\sigma)$ daarvan? ${ }^{7}$ Op basis van een symmetrische indeling van de grenzen en een kwantielenverdeling van $2 \times 10 \%$ 'relatief erg groot/klein', $2 \times 20 \%$

7. Naast de "gewone" Gini-Hirschman coëfficiënt is door ons ook de gecorrigeerde GiniHirschman (GGH) coëfficiënt bepaald, volgens onderstaande formule (Borghans, 1988):

$$
G G H=1-\sqrt{1-G H}
$$

Deze alternatieve berekeningswijze van de spreidingsindicatoren levert echter geen additionele informatie op, mede doordat de grenzen ook opschuiven en daardoor de typering van de onderscheiden opleidingsrichtingen en beroepen niet verandert ten opzichte van de gewone Gini-Hirschman. Omdat de gewone Gini-Hirschman coëfficiënt makkelijk is te interpreteren zullen slechts de resultaten van deze indicator worden gepresenteerd. 
'relatief groot/klein' en $1 \times 40 \%$ 'gemiddeld' worden de grenzen met behulp van schema 5 vastgelegd (zie Wieling, De Grip en Willems, 1990).

Schema 5. Typering van arbeidsmarktinformatie

de te typeren variabele

$x \leq \mu-1,282 \sigma$

$\mu-1,282 \sigma<x \leq \mu-0,524 \sigma$

$\mu-0,524 \sigma<x \leq \mu+0,524 \sigma$

$\mu+0,524 \sigma<x \leq \mu+1,282 \sigma$

$\mu+1,282 \sigma<x$ typering

\author{
relatief erg klein \\ relatief klein \\ gemiddeld \\ relatief groot \\ relatief erg groot
}

Bron: Wieling, De Grip en Willems (1990).

Een nadeel van deze methode is echter dat er geen absolute uitspraken kunnen worden gedaan, omdat de typeringen zijn toegekend op basis van de voor de MDGO-ers bepaalde grenzen ${ }^{8}$. Om meer eenduidige uitspraken te kunnen doen over de waarden van de berekende spreidingsindicatoren zou de typering moeten plaatsvinden op basis van representatieve gegevens over de volle breedte van het onderwijs. Er zijn echter op het gedesaggreerde niveau van de RUBS-data, geen landelijke data beschikbaar om een algemeen geldende kwalitatieve typering te berekenen. In deze studie wordt derhalve alleen uitgegaan van de data van de MDGO-schoolverlaters. De typering positioneert derhalve alleen de desbetreffende opleidingsrichting ten opzichte van de overige MDGO-richtingen. Voor elke afzonderlijke spreidingsindicator worden specifieke grenzen vastgesteld, aan de hand waarvan de berekende resultaten zullen worden ingedeeld. Hoe deze grenzenindelingen luiden, zal telkens bij de betreffende spreidingsindicator worden vermeld.

Overigens moet worden bedacht dat de spreidingsindicator alleen geen eenduidige uitspraak over de positie van de schoolverlaters op de arbeidsmarkt toelaat. Een lage Gini-Hirschman coëfficiënt betekent bijvoorbeeld niet automatisch dat een schoolverlater uit een bepaalde opleidingsrichting van het MDGO slechts in één of enkele beroep(en) of branche(s) terecht kan komen. Een eenduidige beoordeling van de arbeidsmarktpositie van gediplomeerde MDGO-ers kan pas worden gegeven als de spreidingsindicatoren in samenhang met andere indicatoren worden bekeken. In de rest van dit hoofdstuk zullen derhalve de berekende beroepen- en branchespreiding van opleidingsrichtingen in verband worden gebracht met het werkloosheidspercentage per opleidingsrichting.

8. Idealiter zouden deze typeringen moeten worden geijkt aan het gemiddelde en de standaarddeviatie van de coëfficiënten voor het gehele onderwijs, of voor het gehele Middelbare Beroepsonderwijs (MBO). Hiervoor was de pilotversie van de RUBS-enquête echter niet toereikend. 


\subsection{Beroepenspreiding van opleidingen}

Als eerste wordt de Gini-Hirschman coëfficiënt bepaald om na te gaan of er een exclusieve relatie bestaat tussen een opleiding en een bepaald beroep (naïeve model) of dat er een flexibiliteit in de aansluiting tussen opleidingen en beroepen aanwezig is. Met behulp van flexibiliteitsindicatoren kunnen de uitwijkmogelijkheden die men heeft, wanneer men kiest voor een bepaalde opleidingsrichting, worden aangegeven. Bovendien geven deze indicatoren een indruk van de mate waarin men zich met de keuze van een studie of beroep vastlegt voor een specifieke loopbaan.

$$
S O B_{k}=\left(1-\sum_{i=1}^{I} \gamma_{k i}^{2}\right) \frac{I}{I-1}
$$

Met: $S O B_{k}=$ Gini-Hirschman coëfficiënt beroepenspreiding van opleiding $\mathrm{k}$

$\gamma_{k i}=$ aandeel opleiding $\mathrm{k}$ werkzaam in beroep $\mathrm{i}$

I $\quad=$ aantal beroepen

Er wordt enigszins gecorrigeerd voor het gekozen aggregatieniveau door middel van de correctieterm $\frac{I}{I-1}$.

In onderstaand schema wordt aangegeven hoe de grenzenindeling voor de beroepsgroepenspreiding van opleidingsrichtingen er voor de MDGO-schoolverlaters uit komt te zien als de in paragraaf 5.1 besproken methode wordt toegepast.

Schema 6. Typering van de beroepsgroepenspreiding van opleidingsrichtingen

de beroepsgroepenspreiding

van opleidingsrichtingen typering

$$
\begin{aligned}
& \text { relatief erg klein } \\
& \text { relatief klein } \\
& \text { gemiddeld } \\
& \text { relatief groot } \\
& \text { relatief erg groot }
\end{aligned}
$$

$\mathrm{Er}$ is bij deze spreidingsindicator uitgegaan van de beroepsgroepenspreiding (3-digitniveau) van opleidingsrichtingen, vanwege het feit dat er ook rekening zal worden gehouden met de 
functieniveaus behorende bij de beroepen die de werkende schoolverlaters uitoefenen. Het is niet goed mogelijk om functieniveaus aan beroepsklassen toe te kennen. Derhalve is de beroepenspreiding van opleidingsrichtingen bepaald op basis van beroepsgroepen.

In tabel 10 staan de Gini-Hirschman coëfficiënten met betrekking tot de beroepsgroepenspreiding van de onderscheiden MDGO-richtingen. Hier geldt dat de spreidingscoëfficiënten voor de richtingen: verzorging, assistenten gezondheidszorg, uiterlijke verzorging en verpleging relatief laag zijn. De Gini-Hirschman coëfficiënten van deze richtingen liggen onder de waarde 0,6 , hetgeen betekent dat er sprake is van een relatief kleine spreiding. In de richtingen agogisch werk, civiele \& consumptief-technische diensten en mode en kleding treedt er daarentegen een grote beroepenspreiding op. Er kan als gevolg van de berekende resultaten worden geconcludeerd dat de relatie tussen opleidingen en beroepen voor de MDGOschoolverlaters niet wordt getypeerd door het naïeve model, maar ook niet door een volledige flexibiliteit.

Tabel 10. De beroepsgroepenspreiding van opleidingsrichtingen

\begin{tabular}{lll} 
richting & SOB & typering \\
\hline Verzorging & & \\
Sociale arbeid & 0,52 & relatief klein \\
Agogisch werk & 0,75 & gemiddeld \\
Assistenten gezondheidszorg & 0,78 & relatief groot \\
Civiel \& cons-techn diensten & 0,59 & relatief $k$ lein \\
Mode en kleding & 0,80 & relatief groot \\
Activiteitenbegeleiding & 0,78 & relatief groot \\
Sport en beweging & 0,64 & gemiddeld \\
Uiterlijk verzorging & 0,67 & gemiddeld \\
Verpleging & 0,41 & relatief erg klein \\
Overige gediplomeerden & 0,58 & relatief klein \\
\end{tabular}

In figuur 2 worden de landelijke werkloosheidspercentages afgezet tegen de beroepsgroepenspreiding van de MDGO-richtingen. Deze twee indicatoren kunnen op twee, tegengestelde, manieren samenhangen. Ten eerste, kan een hoge spreidingscoëfficiënt wijzen op veel uitwijkmogelijkheden, als gevolg waarvan de werkloosheid voor de betreffende opleiding laag zal zijn. De samenhang tussen de twee indicatoren zal in dit geval negatief zijn. Daartegenover kan echter een andere redenering worden gezet. Een hoge werkloosheid in een bepaalde richting geeft aanleiding tot een grotere spreidingsgraad, omdat schoolverlaters die in hun eigen beroepsdomein geen baan kunnen krijgen, in andere beroepen proberen werk te vinden. In dit geval is er sprake van een positieve samenhang tussen de indicatoren. 
Figuur 2 wijst in de richting van de positieve samenhang tussen beide indicatoren. De richtingen: verzorging, assistenten gezondheidszorg, uiterlijke verzorging en verpleging hebben namelijk zowel een laag werkloosheidspercentage als een lage Gini-Hirschman coëfficiënt. De verklaring hiervoor is waarschijnlijk, dat er voldoende vraag is naar schoolverlaters met deze opleidingsrichtingen in hun "eigen" beroepsdomein. Schoolverlaters met deze opleidingsrichtingen zullen derhalve niet vaak terecht komen in andere beroepen. Voor met name de richtingen sport en beweging, mode en kleding, sociale arbeid en agogisch werk geldt het tegenovergestelde. Deze schoolverlaters komen moeilijk in hun "eigen" beroepsdomein aan de slag en zoeken daarom werk in andere beroepen, hetgeen overigens maar gedeeltelijk lukt.

Figuur 2. Relatie tussen het werkloosheidspercentage en de beroepenspreiding van de opleidingsrichtingen*

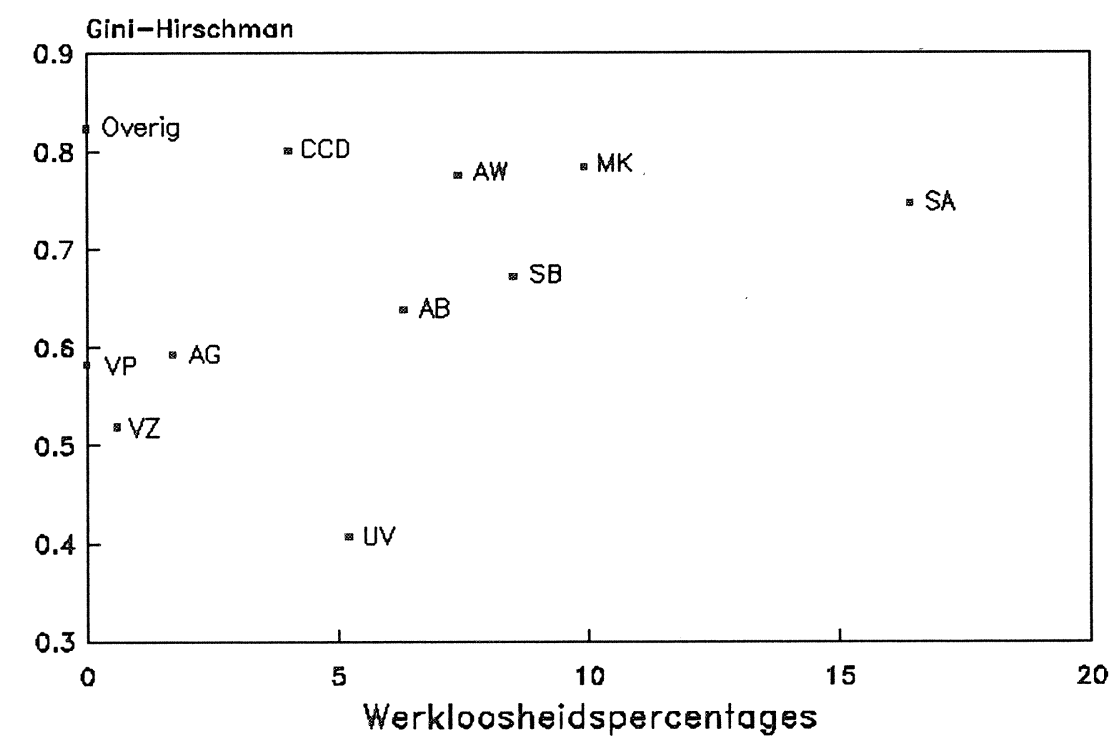

* Zie pagina 5 voor een lijst met afkortingen van de onderscheiden opleidingsrichtingen.

Bovenstaande spreidingscoëfficiënten zijn berekend op basis van alle beroepen die door de MDGO-schoolverlaters op het moment van de enquête werden uitgeoefend. Er is daarbij geen rekening gehouden met het functieniveau van de banen waarnaar men uitwijkt, met andere woorden: de onderbenutting van de schoolverlaters blijft buiten beeld. Het ligt, zoals gezegd, voor de hand dat een schoolverlater die aanvankelijk geen werk kan vinden dat op zijn voltooide opleiding aansluit, een baan zal aanvaarden die minder op zijn studie aansluit. De discrepantie die in dat geval ontstaat kan betrekking hebben op de richting en/of op het niveau van het werk. Indien men echter voor de verschillende richtingen een uitspraak wil doen over de uitwijkmogelijkheden op de arbeidsmarkt in positieve zin, moeten de functies waarin sprake is van onderbenutting niet worden meegenomen. Om hiervan een beeld te krijgen is de 
beroepenspreiding van opleidingsrichtingen ook bepaald door alleen te kijken naar beroepen met een functieniveau van 4 of hoger (zie schema 3 ).

Er moet echter wel worden bedacht dat bij de beroepenspreiding van opleidingsrichtingen, die de onderbenutting buiten beschouwing laat, het aantal beroepsgroepen dat wordt meegenomen kleiner is dan het totaal door het CBS onderscheiden beroepsgroepen.

Tabel 11 geeft een overzicht van de arbeidsmarktflexibiliteit van de opleidingsrichtingen, indien de uitwijkmogelijkheden naar functies die een onderbenutting van het kwalificatieniveau van de schoolverlaters impliceren buiten beschouwing worden gelaten en slechts de beroepen met functieniveau 4, 5, 6 en 7 ("aansluiting en overbenutting") worden meegenomen bij de bepaling van de spreidingscoëfficiënten.

De grenzenindeling voor deze beroepenspreiding van opleidingsrichtingen is hier opnieuw vastgesteld. De kwalitatieve typering van deze spreidingsindicator is in dit geval met behulp van onderstaande grenzenindeling is toegekend:

Schema 7. Typering van de beroepsgroepenspreiding van opleidingsrichtingen

De spreidingscoëfficiënten voor de opleidingsrichtingen agogisch werk, activiteitenbegeleiding, sport en beweging, uiterlijke verzorging en verpleging zijn kleiner ten opzichte van de coëfficiënten die geen rekening houden met het functieniveau. De waarden liggen in dit geval onder 0,5. Dit wijst erop dat als MDGO-schoolverlaters uit deze opleidingsrichtingen uitwijken naar andere beroepen, zij vaker uitwijken naar beroepen met een lager niveau. Dit spoort met de hoge percentages onderbenutting die reeds in hoofdstuk 4 zijn besproken (zie tabel 7). De andere coëfficiënten blijken niet veel af te wijken van de eerder berekende spreidingscoëfficiënten (zie tabel 10). De typering kan echter wel iets veranderen, omdat de grenzenindeling hier anders is. 
Tabel 11. De beroepsgroepenspreiding van opleidingsrichtingen (exclusief onderbenutting)

\begin{tabular}{lll}
\hline & SOB & typering \\
\hline richting & & \\
& & gemiddeld \\
Verzorging & 0,51 & relatief groot \\
Sociale arbeid & 0,70 & relatief klein \\
Agogisch werk & 0,39 & gemiddeld \\
Assistenten gezondheidszorg & 0,55 & relatief groot \\
Civiel \& cons-techn. diensten & 0,80 & relatief groot \\
Mode en kleding & 0,78 & gemiddeld \\
Activiteitenbegeleiding & 0,42 & relatief klein \\
Sport en beweging & 0,55 & relatief erg klein \\
Uiterlijke verzorging & 0,08 & relatief klein \\
Verpleging & 0,28 & relatief groot \\
Overige gediplomeerden & 0,70 & \\
\end{tabular}

Ook de coëfficiënten van beroepenspreiding van opleidingsrichtingen, waarbij wordt gecorrigeerd voor onderbenutting, kunnen worden afgezet tegen de werkloosheidspercentages van MDGO-schoolverlaters die in het bezit zijn van het diploma (zie figuur 3). In dit geval is de positieve samenhang tussen de beide indicatoren minder duidelijk traceerbaar dan in het geval waar geen rekening wordt gehouden met onderbenutting. Hieruit kan worden geconcludeerd dat de schoolverlaters in geval van hoge werkloosheid inderdaad uitwijken naar beroepen met een lager functieniveau.

Figuur 3. Relatie tussen het werkloosheidspercentage en de beroepenspreiding van de opleidingsrichtingen voor beroepen met functieniveau $4,5,6$ of $7^{*}$

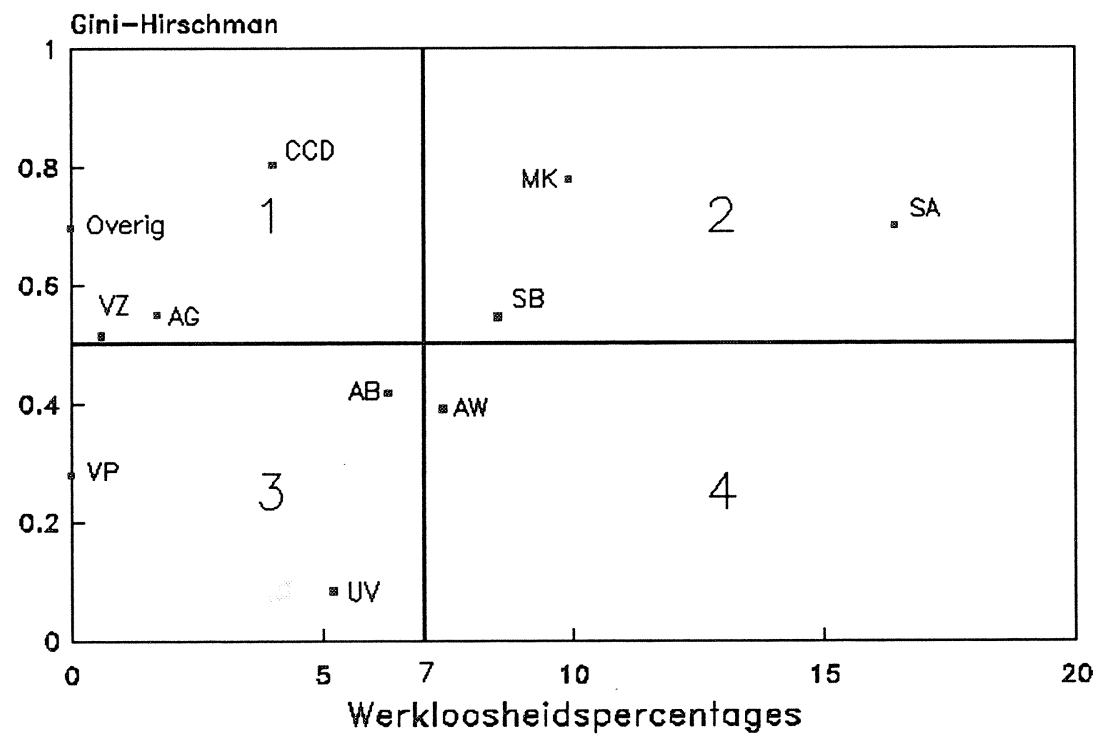

* Zie pagina 5 voor een lijst met afkortingen van de onderscheiden opleidingsrichtingen. 
Wellicht kan nu op basis van de relatie tussen de werkloosheidspercentages en de GiniHirschman coëfficiënt een uitspraak worden gedaan over de positie van gediplomeerde MDGOers op de arbeidsmarkt. Figuur 3 kan in vier vlakken worden gedeeld. Men kan veronderstellen dat er sprake is van een slechte arbeidsmarktpositie voor schoolverlaters uit een bepaalde opleidingsrichting, indien het werkloosheidspercentage hoog is en de spreidingsindicator laag (vlak 4). Behalve wellicht agogisch werk heeft echter geen enkele opleidingsrichting deze twee negatieve kenmerken. Bij een geringe werkloosheid en een hoge spreidingsgraad zou men daarentegen kunnen spreken van een goede arbeidsmarktpositie, omdat de gediplomeerde schoolverlaters van de desbetreffende richting een grote kans op werk en veel uitwijkmogelijkheden hebben (vlak 1). Derhalve kan er voor de richtingen verzorging, assistenten gezondheidszorg en civiele \& consumptief-technische diensten worden gesproken van een gunstige arbeidsmarktpositie. Met betrekking tot de overige opleidingsrichtingen kan geen eenduidige uitspraak worden gedaan over de arbeidsmarktpositie van de MDGO-schoolverlaters (vlakken 2 en 3).

\subsection{Branchespreiding van opleidingen}

Om een indruk te krijgen van de bedrijfsklassen waarin de gediplomeerde MDGO-schoolverlaters terecht komen is, naast de beroepsgroepenspreiding van de opleidingsrichtingen, ook de bedrijfsklassenspreiding van de opleidingsrichtingen bepaald met behulp van onderstaande formule, waarbij voor het gekozen aggregatieniveau wordt gecorrigeerd door middel van de correctieterm $\frac{J}{J-1}$ :

$$
S O B R_{k}=\left(1-\sum_{j=1}^{J} \beta_{k j}^{2}\right) \frac{J}{J-1}
$$

Met: $S O B R_{k}=$ Gini-Hirschman coëfficiënt branchespreiding van opleiding $\mathrm{k}$

$\beta_{k j} \quad=$ andeel opleiding $\mathrm{k}$ werkzaam in bedrijfstak $\mathrm{j}$

$J \quad=$ aantal bedrijfstakken

Bovenstaande branchespreiding van de opleidingsrichtingen is overigens bepaald voor bedrijfsklassen (2-digitniveau). De reden hiervoor is dat de coëfficiënten hoger zullen zijn naarmate het niveau van de branches minder geaggregeerd is, omdat het aantal branches waarin de opleidingsrichtingen kunnen voorkomen bij een lager aggregatieniveau groter is, als gevolg waarvan het onderscheidingsvermogen van de maatstaf afneemt. 
Evenals voor de beroepenspreiding van opleidingsrichtingen is voor de branchespreiding van opleidingsrichtingen een grenzenindeling vastgesteld met behulp van het gemiddelde en de standaarddeviatie van de berekende waarden van de betreffende spreidingscoëfficiënt. De grenzenindeling die resulteert staat weergegeven in schema 8.

Schema 8. Typering van de bedrijfsklassenspreiding van opleidingsrichtingen

de bedrijfsklassenspreiding typering

van opleidingsrichtingen

relatief erg klein

relatief klein

$0,00<$ SOBR $\leq 0,50$

$0,50<\mathrm{SOBR} \leq 0,60$

gemiddeld

$0,60<$ SOBR $\leq 0,75$

$0,75<$ SOBR $\leq 0,85$

relatief groot

$0,85<\mathrm{SOBR} \leq 1,00$

relatief erg groot

In tabel 12 staan de coëfficiënten die een indicatie geven van de spreiding van de opleidingsrichtingen over de verschillende bedrijfstakken (waarbij er wordt gecorrigeerd voor het gekozen aggregatieniveau). De tabel laat zien dat de Gini-Hirschman coëfficiënten voor de richtingen verzorging, assistenten gezondheidszorg, uiterlijke verzorging en verpleging relatief laag zijn. De Gini-Hirschman coëfficiënten van deze richtingen liggen tussen 0,4 en 0,6, hetgeen betekent dat er sprake is van een relatief kleine of relatief erg kleine branchespreiding van deze opleidingsrichtingen.

Tabel 12. De bedrijfsklassenspreiding van opleidingsrichtingen

\begin{tabular}{lll}
\hline richting & SOBR & typering \\
\hline Verzorging & & \\
Sociale arbeid & 0,54 & relatief klein \\
Agogisch werk & 0,87 & relatief erg groot \\
Assistenten gezondheidszorg & 0,70 & gemiddeld \\
Civiele \& cons-techn diensten & 0,54 & relatief klein \\
Mode en kleding & 0,80 & relatief groot \\
Activiteitenbegeleiding & 0,68 & gemiddeld \\
Sport en beweging & 0,65 & gemiddeld \\
Uiterlijke verzorging & 0,76 & relatief groot \\
Verpleging & 0,45 & relatief erg klein \\
Overige gediplomeerden & 0,59 & relatief klein \\
& 0,82 & relatief groot \\
\hline
\end{tabular}

In figuur 4 worden de landelijke werkloosheidspercentages afgezet tegen de bedrijfsklassenspreiding van de MDGO-richtingen. Ook in dit geval kunnen de indicatoren op twee wijzen samenhangen. De indicatoren kunnen op positieve wijze zijn gecorreleerd, doordat 
er bij een hoog werkloosheidspercentage veel prikkels tot spreiding zijn. Bij een negatieve samenhang is er al dan niet sprake van structureel grote uitwijkmogelijkheden, als gevolg waarvan de werkloosheid laag is. Figuur 4 lijkt meer in de richting van eerstgenoemde samenhang te wijzen. Opvallend is namelijk dat de richtingen: verzorging, assistenten gezondheidszorg, uiterlijke verzorging en verpleging zowel een laag werkloosheidspercentage als lage Gini-Hirschman coëfficiënten hebben. Waarschijnlijk is er veel vraag naar schoolverlaters met deze opleidingsrichtingen in de "eigen" branches, waardoor schoolverlaters met deze opleidingsrichtingen minder vaak terecht komen in andere bedrijfsklassen. Daarentegen geldt met name voor de richtingen sport en beweging, mode en kleding, sociale arbeid en agogische werk het tegenovergestelde. Deze schoolverlaters komen niet in hun "eigen" branches aan de slag en zoeken daarom werk in andere bedrijfsklassen, hetgeen maar gedeeltelijk lukt. Met name de schoolverlaters uit de richting sociale arbeid laten zowel een hoge spreidingscoëfficiënt als een hoog werkloosheidspercentage zien.

Figuur 4. Relatie tussen het werkloosheidspercentage en de branchespreiding van de opleidingsrichtingen"

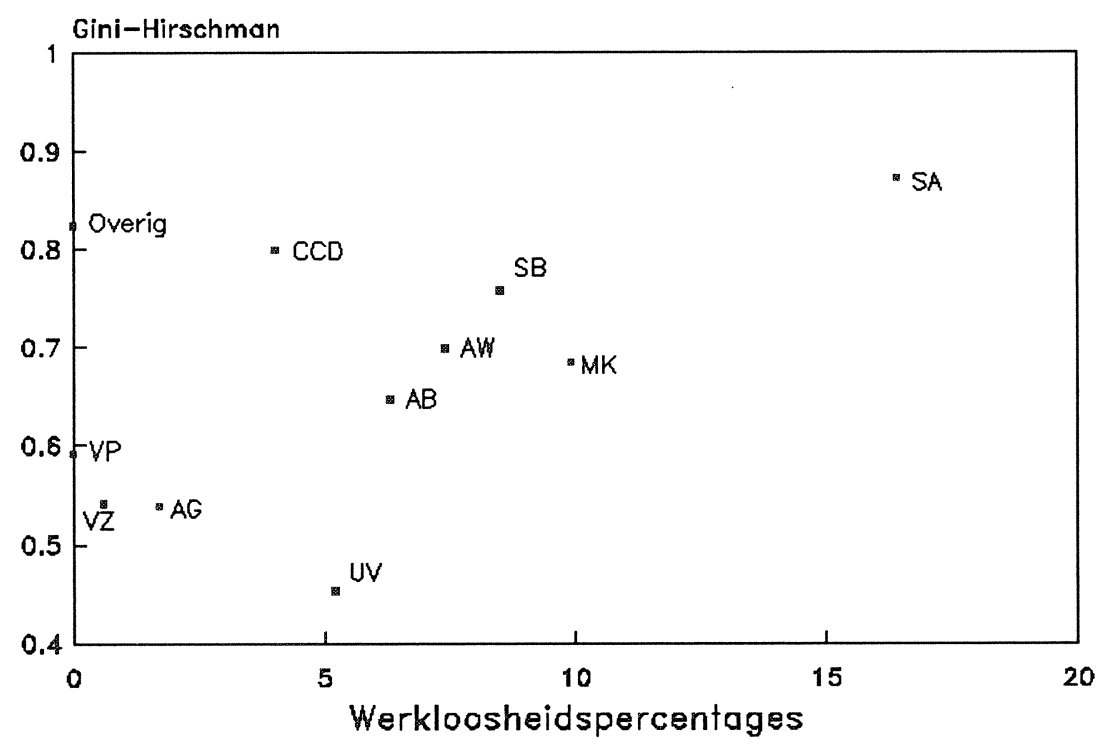

\footnotetext{
* Zie pagina 5 voor een lijst met afkortingen van de onderscheiden opleidingsrichtingen.
} 


\subsection{Opleidingspreiding van beroepen}

Naast bovenstaande Gini-Hirschman coëfficiënten is ook de opleidingsrichtingenspreiding van beroepsgroepen bepaald ${ }^{9}$. Deze indicator geeft een indruk van de mate waarin de onderscheiden richtingen onderling concurrerend zijn met betrekking tot de uitoefening van een bepaald beroep. Ook deze indicator kan waarden aannemen tussen 0 en 1 . De indicator is 0 als het beroep wordt uitgeoefend door personen die allemaal dezelfde opleidingsrichting hebben en 1 als het beroep door mensen met verschillende opleidingsrichtingen wordt uitgeoefend. In geval van het huidige RUBS-gegevensbestand is het gebruik van deze indicator eigenlijk niet geheel juist. Immers als men de opleidingspreiding van een beroepsgroep wil berekenen, moet men gegevens moet hebben met betrekking tot de gevolgde opleiding van alle personen in die betreffende beroepsgroep. In de huidige analyse is echter slechts gebruik gemaakt van gegevens over MDGO-schoolverlaters. Echter voor beroepen die tot het traditionele domein van bepaalde richtingen kunnen worden gerekend en enkele andere beroepsgroepen waar relatief veel schoolverlaters terecht komen kan worden bepaald of de specifieke richting die men op het MDGO heeft gevolgd er toe doet.

In dit geval heeft de opleidingsrichtingenspreiding van beroepsgroepen meer het karakter van een concurrentiecoëfficiënt. De Gini-Hirschman coëfficiënt is hier niet zo zeer een indicatie van spreiding, maar zegt het iets over de mate waarin MDGO-ers uit de verschillende afstudeerrichtingen elkaar op de arbeidsmarkt beconcurreren.

$$
S B O_{i}=\left(1-\sum_{k=1}^{K} \theta_{k i}^{2}\right) \frac{K}{K-1}
$$

Met: $S B O_{i}=$ Gini-Hirschman coëfficiënt opleidingspreiding van beroep $\mathrm{i}$

$\theta_{k i} \quad=$ aandeel werkenden in beroep i met opleiding $\mathrm{k}$

$K \quad=$ aantal opleidingen

Ook in dit geval wordt er gecorrigeerd voor het gekozen aggregatieniveau. Bij bovenstaande spreidingsindicator is gecorrigeerd voor het aantal onderscheiden beroepen door middel van de correctieterm $\frac{K}{K-1}$.

$9 \mathrm{Er}$ is in dit geval uitgegaan van beroepsgroepen, omdat op 2-digitniveau een aantal voor het MDGO belangrijke beroepsgroepen worden samengenomen. Dit geeft meteen het grote voordeel van de RUBS-data aan, namelijk dat deze zo gedesaggregeerd zijn. 
Schema 9. Typering van de opleidingsrichtingenspreiding van beroepsgroepen

de opleidingsrichtingen- typering

spreiding van beroepsgroepen
$0,00<\mathrm{SBO} \leq 0,05$
$0,05<\mathrm{SBO} \leq 0,25$
$0,25<\mathrm{SBO} \leq 0,55$
$0,55<\mathrm{SBO} \leq 0,75$
$0,75<\mathrm{SBO} \leq 1,00$
relatief erg klein
relatief klein
gemiddeld
relatief groot
relatief erg groot

Tabel 13. De opleidingsrichtingenspreiding van enkele beroepsgroepen

\begin{tabular}{|c|c|c|c|}
\hline beroepsgroep & aantal & SBO & typering \\
\hline Apothekersassistenten & 344 & 0,00 & geen spreiding \\
\hline Overige verplegenden & 477 & 0,67 & relatief groot \\
\hline Kraamverzorgsters & 207 & 0,01 & relatief erg klein \\
\hline Fysio-, arbeidstherapeuten & 158 & 0,37 & gemiddeld \\
\hline Boekhouders, kassiers & 183 & 0,83 & relatief erg groot \\
\hline Winkelbedienden e.a.verkopers & 393 & 0,57 & relatief groot \\
\hline Koks en keukenhulpen & 97 & 0,36 & gemiddeld \\
\hline Kelners, buffetbedienden & 78 & 0,73 & relatief groot \\
\hline Verzorgend personeel & 1077 & 0,46 & gemiddeld \\
\hline Kappers, schoonheidsspecialisten e.d. & 136 & 0,02 & relatief erg klein \\
\hline Dokters-, tandarts-, dierenartsassistenten & 375 & 0,08 & relatief klein \\
\hline
\end{tabular}

Voor de beroepsgroep in de administratieve functies geldt dat de spreidingscoëfficiënt vrij hoog is. Dit is ook af te leiden uit de aandelen van de opleidingsrichtingen in de beroepsgroepen. Dit wijst erop dat de richting die men binnen het MDGO heeft gevolgd hier niet van belang is. De Gini-Hirschman coëfficiënten voor apothekersassistenten en kraamverzorgsters zijn daarentegen erg laag. De apothekersassistenten komen allemaal uit dezelfde opleidingsrichting en wel assistenten gezondheidszorg. Dit is een duidelijk voorbeeld van een arbeidsmarktsegment dat wordt getypeerd door het ideaal-typische naïeve model. Men spreekt in dit verband wel van een vakdeelmarkt. Voor kraamverzorgsters geldt dat zij vrijwel allemaal afkomstig zijn uit de richting verzorging, slechts $1 \%$ heeft assistenten gezondheidszorg gedaan. De coëfficiënt voor de beroepsgroep overige verplegenden (hiertoe behoren de leerling-verpleegkundige $A, B, Z$, de ziekenverzorgster, zwakzinnigenverzorgster en de ziekenverzorgster, zwakzinnigenverzorgster in opleiding) is hoog. Ruim de helft van de overige verplegenden heeft agogisch werk gedaan en nog eens een derde komt van MDGO-verzorging, hetgeen betekent dat er niet sprake is van een eenduidige relatie tussen opleidingsrichting en beroep. De fysio- en arbeidstherapeuten kennen een gemiddelde spreiding. $80 \%$ van de schoolverlaters die in deze beroepsgroep werken heeft 
de opleidingsrichting activiteitenbegeleiding afgesloten.

Voor een tweetal beroepsgroepen van de dienstverlenende functies is de Gini-Hirschman coëfficiënt laag, namelijk voor kappers en schoonheidsspecialisten $199 \%$ van uiterlijke verzorging) en voor de dokters-, tandarts-, dierenartsassistenten $196 \%$ heeft de richting assistenten gezondheidszorg gedaan). De spreiding voor de beroepsgroep kelners en buffetbedienden is daarentegen relatief groot. In deze beroepsgroep komt $51 \%$ van civiele \& consumptief-technische diensten en $21 \%$ en $18 \%$ van respectievelijk agogisch werk en mode en kleding. Het overig verzorgend personeel vertoont een gemiddelde spreiding, respectievelijk $73 \%$ en $23 \%$ heeft verzorging en agogisch werk gedaan, net zoals de beroepsgroep koks en keukenhulpen $(81 \%$ is afkomstig van civiele \& consumptief-technische diensten). Voor de beroepsgroep behorende tot de commerciële functies, namelijk winkelbedienden en andere verkopers (excl. vertegenwoordigers), geldt dat er sprake is van een relatief grote spreiding. Hiermee kan tenslotte meteen een punt van kritiek op de Gini-Hirschman coëfficiënt worden aangegeven; want alhoewel de Gini-Hirschman coëfficiënt vrij hoog is, is desalniettemin ruim twee derde van de MDGO-schoolverlaters in deze beroepsgroep afkomstig uit de opleidingsrichting mode en kleding. De Gini-Hirschman coëfficiënt heeft, zoals al in paragraaf 5.1 reeds werd genoemd, namelijk al gauw de neiging om snel groter te worden ook al is, bijvoorbeeld in dit geval, een groot deel van de werkende MDGO-ers in een bepaalde beroepsgroep afkomstig uit éen opleidingsrichting. Het valt echter buiten de doelstellingen van dit rapport om hierop uitvoerig in te gaan. 


\section{BESLUIT}

In het kader van de ontwikkeling van het informatiesysteem onderwijs-arbeidsmarkt zijn in deze studie enkele indicatoren ontwikkeld. De doelstelling is het empirisch invullen van enkele belangrijke, door De Grip en Heijke (1988) reeds besproken, arbeidsmarktindicatoren. Dit is gebeurd aan de hand van de data die verkregen zijn uit de RUBS-schoolverlatersenquête 1989. Daarbij is tevens getracht te achterhalen welke mogelijkheden de RUBS-schoolverlatersenquête biedt voor het construeren van indicatoren met betrekking tot de aansluiting onderwijsarbeidsmarkt op een laag aggregatieniveau naar opleidingsrichting.

In de RUBS-pilotstudie van april/mei 1989 is geprobeerd om tenminste voor éen onderwijstype de schoolverlaters in alle deelnemende regio's te onderzoeken. Dat onderwijstype is het MDGO geworden. De dekkingsgraad van de gediplomeerde MDGO-ers bedraagt gemiddeld $52 \%$, maar varieert tussen de regio's en tussen de opleidingsrichtingen. De dekkingsgraad onder voortijdige schoolverlaters is lager, omdat de registratie van de ongediplomeerden bij de deelnemende scholen niet altijd even nauwkeurig was. De gemiddelde respons van de gediplomeerde MDGOers is vrij hoog, namelijk $74 \%$. De respons van de ongediplomeerde MDGO-schoolverlaters bedraagt $43 \%$.

Vaak wordt in aansluitingsonderzoek de arbeidsmarktpositie van schoolverlaters getypeerd aan de hand van slechts een enkel kengetal, zoals het werkloosheidspercentage of het gemiddelde functieniveau. Voor een evenwichtige beschouwing van de arbeidsmarktpositie is het evenwel van belang om over meerdere indicatoren te beschikken, die bovendien de verschillende aspecten van de arbeidsmarkt dekken. In deze studie zijn hiervoor een aantal indicatoren ontwikkeld en kwalitatief getypeerd. Met betrekking tot de kans op werk en de arbeidszekerheid is het werkloosheidspercentage en de conjunctuurgevoeligheid van de werkgelegenheid van de opleidingsrichtingen bepaald. Met betrekking tot de inhoud van het werk en de aansluiting bij de gevolgde opleiding is gekeken naar het gemiddelde functieniveau, het percentage onderbenutting, het gemiddelde inkomen en het percentage schoolverlaters dat minder verdient dan het minimumloon. Met betrekking tot de mobiliteitsmogelijkheden op de arbeidsmarkt tenslotte is gekeken naar de verschillende uitwijkmogelijkheden of flexibiliteit (branche- en beroepenspreiding van opleidingen en opleidingspreiding van beroepen). De afzonderlijke indicatoren zijn bovendien met elkaar in verband gebracht en op basis daarvan is geprobeerd een typering van de arbeidsmarkt te geven voor de onderscheiden opleidingsrichtingen binnen het MDGO.

Van de 26509 schoolverlaters die hebben gereageerd op de RUBS-enquête zijn 7417 leerlingen 
afkomstig van het MDGO. Gemiddeld is $82 \%$ van deze MDGO-schoolverlaters in het bezit van het diploma. De voortijdige schoolverlaters zijn als éen groep in deze studie opgenomen. Dit is niet alleen gebeurd omdat de aantallen klein waren, maar vooral omdat het weinig zinvol is de bestemming van schoolverlaters te relateren aan een opleiding die zij niet hebben afgemaakt en waarvan de opleidingsdoelstellingen dus niet volledig kunnen zijn gerealiseerd.

Wat betreft de voornaamste bezigheid op het moment van de enquête blijkt dat ongeveer $80 \%$ van de gediplomeerde schoolverlaters is ingestroomd op de arbeidsmarkt. Hiervan heeft $80 \%$ een baan gevonden, $5 \%$ was op het moment van enquetering werkloos en de overige $15 \%$ is doorgestroomd naar een deeltijd opleiding. Daarnaast heeft $15 \%$ van de diplomabezitters zijn of haar opleiding in het voltijd onderwijs voortgezet. De mogelijk zwakkere positie van voortijdige MDGO-schoolverlaters op de arbeidsmarkt kan op basis van de RUBS-data niet worden aangetoond. Bijna $40 \%$ van de ongediplomeerden leert door binnen het voltijd of deeltijd onderwijs. De opleidingsweg van deze leerlingen is misschien niet efficiënt, maar waarschijnlijk ondervinden de voortijdige schoolverlaters op langere termijn weinig schade van het voortijdig afbreken van de studie aan het MDGO. Bij de voortijdige schoolverlaters die een full-time baan zijn gaan zoeken, kan niet worden geconcludeerd dat de arbeidsmarktpositie van ongediplomeerden zonder meer slechter is dan die van de diplomabezitters. De periode tussen het verlaten van het MDGO en het moment van enquêteren is te kort om hierover eenduidige uitspraken te kunnen doen.

In deze studie is, zoals gezegd, een aantal indicatoren ontwikkeld met betrekking tot de aansluiting tussen onderwijs en arbeidsmarkt voor de diverse opleidingsrichtingen binnen het MDGO. Als eerste is de werkloosheid onder degenen die zich aanbieden op de arbeidsmarkt berekend. Aan deze werkloosheidspercentages zijn op basis van de indeling van Van Paridon kwalitatieve typeringen toegekend. Indien de werkloosheid gelijk is aan de frictiewerkloosheid is er sprake van evenwicht op de arbeidsmarkt. Gemiddeld bedraagt het werkloosheidspercentage onder alle gediplomeerde MDGO-ers $5 \%$, hetgeen wijst op een aanbodtekort op de arbeidsmarkt. Het werkloosheidspercentage van de ongediplomeerden bedraagt $8 \%$. Dit betekent dat de arbeidsmarkt voor voortijdige schoolverlaters, volgens Van Paridon, in evenwicht is. Indien de werkloosheid per opleidingsrichting wordt bezien, kan het volgende worden geconcludeerd. In de richtingen sociale arbeid, mode en kleding en sport en beweging is sprake van een overschot aan afgestudeerde MDGO-ers, terwijl voor verzorging, assistenten gezondheidszorg, civiele \& consumptief-technische diensten, activiteitenbegeleiding en uiterlijke verzorging tekorten worden geconstateerd. Bij het opsplitsen van de werkloosheidscijfers naar regio blijkt dat er in de Randstad een groot tekort aan gediplomeerde MDGO-ers is, terwijl er in de rest van Nederland sprake is van een tekort. In beide delen van Nederland is de arbeidsmarkt 
voor voortijdige schoolverlaters in evenwicht.

De conjunctuurindicator geeft aan dat de mate van werkzekerheid in vrijwel alle richtingen gemiddeld is. Uitzonderingen hierop zijn de richtingen mode en kleding die wordt gekenmerkt door een relatief hoge conjunctuurgevoeligheid en de richting uiterlijke verzorging waarin sprake is van een kleine conjunctuurgevoeligheid. Met andere woorden de mogelijkheid bestaat dat het overschot dat in de richting mode en kleding optreedt tijdelijk is. Daarentegen geeft de conjunctuurindicator aan dat het tekort aan MDGO-ers van de richting uiterlijke verzorging waarschijnlijk niet gemakkelijk als gevolg van conjuncturele fluctuaties zullen verdwijnen. De conjunctuurgevoeligheid van de ongediplomeerde schoolverlaters is ongeveer gemiddeld.

$\mathrm{Na}$ de werkloosheid en de mate van werkzekerheid van de MDGO-schoolverlaters, is gekeken naar het soort functie die werkende MDGO-ers bekleden. Als eerste is nagegaan wat het functieniveau is van de baan, die de schoolverlaters op het moment van enquêtering uitoefenen. Het gemiddelde functieniveau van de gediplomeerde schoolverlaters is 3,31 , enigszins onder het geëigende functieniveau voor MBO-opleidingen. De richtingen civiele \& consumptief-technische diensten en mode en kleding worden gekenmerkt door een relatief laag gemiddeld functieniveau, terwijl het gemiddeld functieniveau van activiteitenbegeleiding en sport en beweging relatief hoog is. Hierbij valt echter op dat de standaarddeviatie van het functieniveau van deze vier opleidingsrichtingen groot is. Op basis van de percentages onderbenutting kan worden geconcludeerd dat er sprake is van een grote onderbenutting in de richtingen: verzorging, sociale arbeid, civiele \& consumptief-technische diensten, mode en kleding en verpleging. Gemiddeld ligt de onderbenutting op $58 \%$, terwijl voor $41 \%$ geldt dat de baan wat betreft het functieniveau aansluit op de gevolgde opleiding. Als het percentage onderbenutting in verband wordt gebracht met de werkloosheidspercentages mag worden verwacht dat, indien de schoolverlaters geen baan kunnen krijgen die qua functieniveau aansluit op de gevolgde opleiding, de noodzaak om uit te wijken naar beroepen met een lager functieniveau groter is. Deze positieve relatie tussen beide variabelen wordt enigszins bevestigd door de RUBS-data.

Vervolgens is het gemiddelde netto maandloon (gecorrigeerd voor leeftijd en omvang van de werkweek) bepaald. Het gemiddelde inkomen is relatief hoog in de richtingen: verzorging, assistenten gezondheidszorg, sport en beweging en verpleging. Daarentegen worden de richtingen mode en kleding en uiterlijke verzorging gekenmerkt door een relatief laag gemiddeld inkomen. De inkomensspreiding in de richtingen agogisch werk, mode en kleding, activiteitenbegeleiding en sport en beweging is groot en in de richtingen assistenten gezondheidszorg en verpleging klein. Daarbij moet worden opgemerkt dat van de (full-time) werkenden gemiddeld $13 \%$ van de gediplomeerden minder dan 975 gulden netto per maand 
verdiend. In de richtingen agogisch werk, mode en kleding en uiterlijke verzorging verdient zelfs ongeveer $25 \%$ minder dan 975 gulden per maand. Zoals verwacht is het gemiddelde netto maandloon van de diplomabezitters hoger dan van niet-diplomabezitters. Over alle opleidingsrichtingen bekeken verdienen de schoolverlaters die in het bezit zijn van het diploma netto ongeveer 250 gulden per maand meer dan schoolverlaters zonder diploma.

De flexibiliteit in de aansluiting tussen opleiding en arbeidsmarkt is vervolgens aan de orde gekomen. Het naïeve model gaat er van uit dat er een exclusieve relatie bestaat tussen opleidingen en beroepen. Volgens het flexibiliteitsmodel daarentegen kunnen mensen met een bepaalde opleiding in geheel verschillende beroepen terecht komen. Op basis van de berekende spreidingsindicatoren kan er worden geconcludeerd dat de relatie tussen opleidingen en beroepen noch volledig door het naïeve model, noch volledig door het flexibiliteitsmodel wordt getypeerd. Met betrekking tot de beroepsgroepenspreiding van de opleidingsrichtingen geldt dat de arbeidsmarktflexibiliteit voor de richtingen: verzorging, assistenten gezondheidszorg, uiterlijke verzorging en verpleging relatief laag is, dat wil zeggen relatief ten opzichte van andere MDGOopleidingsrichtingen. In de richtingen: agogisch werk, civiele \& consumptief-technische diensten en mode en kleding treedt er een grote beroepenspreiding op. Indien alleen wordt gekeken naar de beroepen met een voor het MDGO geëigend functieniveau van 4 of hoger kan het volgende worden opgemerkt. De spreidingscoëfficiënten voor de opleidingsrichtingen agogisch werk, assistenten gezondheidszorg, sport en beweging, uiterlijke verzorging en verpleging zijn kleiner ten opzichte van de coëfficiënten die geen rekening houden met de functieniveaus. Dit wijst erop dat als betreffende MDGO-schoolverlaters uitwijken naar andere beroepen dit vaak gebeurt naar beroepen op een lager niveau. De andere spreidingscoëfficiënten wijken niet veel af van de eerder berekende spreidingscoëfficiënten.

Ook zijn er coëfficiënten die een indicatie geven van de spreiding van de opleidingsrichtingen over de verschillende bedrijfsklassen. Voor deze indicator geldt dat de bedrijfsklassenspreiding voor de richtingen: verzorging, assistenten gezondheidszorg, uiterlijke verzorging en verpleging relatief laag is.

Als laatste is de opleidingspreiding van enkele voor het MDGO belangrijke beroepsgroepen bepaald. Deze spreidingsindicator moet in deze studie worden geïnterpreteerd als een concurrentiecoëfficiënt. Een aantal beroepen, zoals apothekersassistenten, kraamverzorgsters, kappers en schoonheidsspecialisten en dergelijke en dokters-, tandarts-, en dierenartsassistenten, hebben een erg lage spreiding naar opleidingsrichting. Dat wil zeggen dat voor zover deze beroepen worden uitgeoefend door MDGO-ers, deze schoolverlaters uit dezelfde richting afkomstig zijn. Dit houdt in dat er geen concurrentie plaatsvindt tussen de verschillende 
opleidingsrichtingen, hetgeen wijst op specifieke vakdeelmarkten, waarop het naïeve model van aansluiting van onderwijs en arbeidsmarkt van toepassing is. De beroepsgroepen in de administratieve en commerciële sectoren vertonen over het algemeen een grotere spreiding.

De spreidingsindicatoren, met uitzondering van de opleidingspreiding van beroepen, zijn telkens beoordeeld in relatie met het werkloosheidspercentage van de desbetreffende opleidingsrichting. $\mathrm{Er}$ is opgemerkt dat de betreffende indicatoren op twee wijzen kunnen samenhangen. Ten eerste, kan een hoge spreidingscoëfficiënt wijzen op veel uitwijkmogelijkheden, als gevolg waarvan de werkloosheid voor betreffende opleiding laag zal zijn. In dit geval is er sprake van een negatief verband. Daartegenover kan ook een positief verband worden verondersteld. Een hoge werkloosheid in een bepaalde richting geeft aanleiding tot een grotere spreiding, omdat schoolverlaters die in hun eigen beroepsdomein of branche geen baan krijgen, in andere beroepen of bedrijfstakken proberen werk te vinden. Voor zowel de beroepenspreiding lop alle functieniveaus en alleen op de functieniveaus van 4 of hoger) als de branchespreiding van opleidingen geldt dat er sprake blijkt te zijn van een positief verband.

Meer inzicht in de arbeidsmarktpositie van de gediplomeerde schoolverlaters kan plaatsvinden indien de spreidingsindicator in samenhang met andere indicatoren wordt bekeken. Derhalve zijn de flexibiliteitsindicatoren in samenhang gebracht met de werkloosheidspercentages. Er is zonder meer sprake van een slechte arbeidsmarktpositie voor schoolverlaters uit een bepaalde opleidingsrichting, indien de betreffende schoolverlaters afkomstig zijn uit een richting waarvoor het werkloosheidspercentage hoog is en de spreidingsindicator laag is. Dit blijkt echter voor geen enkele opleidingsrichting binnen het MDGO het geval te zijn. Bij een geringe werkloosheid en een hoge spreidingsgraad zou men kunnen spreken van een goede arbeidsmarktpositie. Hierbij moet echter worden bedacht dat de MDGO-schoolverlaters nogal eens zijn uitgeweken naar voor hen, qua functieniveau, minder aantrekkelijke banen. In dat geval kan moeilijk worden gesproken van een goede arbeidsmarktpositie. Daarom is het beter de arbeidsmarktflexibiliteit alleen te baseren op de uitwijkmogelijkheden op het voor het MBO geëigende functieniveau of hoger. Op deze manier gedefinieerd is er bij de richtingen verzorging, assistenten gezondheidszorg en civiele \& consumptief-technische diensten sprake van een relatief gunstige arbeidsmarktpositie. Indien de onderbenutting buiten beschouwing blijft, is er voor de richting agogisch werk sprake van een slechte arbeidsmarktpositie. Met betrekking tot de overgebleven opleidingsrichtingen kan geen eenduidige uitspraak worden gedaan. 


\section{LITERATUUR}

Borghans, L. (1988), Een interpretatie van de Gini-Hirschman coëfficiënt, Interne notitie, ROA, Maastricht.

Centraal Planbureau (1988), Centraal Economisch Plan 1988, 's-Gravenhage.

Grip, A. de, J.W. van Dam (1990), Evaluatie van de RUBS-schoolverlatersenquête 1989, ROAR-1990/2, Maastricht.

Grip, A. de, J.A.M. Heijke (1988), Arbeidsmarktindicatoren: een inventarisatie, ROA-W-1988/1, Maastricht.

Grip, A. de, J.A.M. Heijke (1989), Het flexibiliteitspotentieel van universitaire studierichtingen, in: Tijdschrift voor arbeidsmarktvraagstukken, jrg. 5, nr.4, blz. 69-81.

Grip, A. de, J.A.M. Heijke. R.J.P. Dekker (1989), De arbeidsmarkt naar beroep en opleiding in 1992, ROA-R-1989/8, Maastricht.

Hoof, J.J. van, J. Dronkers (1980), Onderwijs en arbeidsmarkt, Sociologische monografieën, Van Loghum Slaterus, Deventer.

Huijgen, F. (1989), De kwalitatieve structuur van de werkgelegenheid in Nederland. Deel III: bevolking in loondienst en functiestructuur in 1977 en 1985, OSA-voorstudie V33, 'sGravenhage.

Laarhoven, P. van, S. Waslander (1990), Uitstroom en bestemming van MDGO-schoolverlaters: een landelijke rapportage over het RUBS-project in 1989, RION, Groningen.

Paridon, W.C.G.M. van (1987), De arbeidsmarktindicator, in: Management Berichten, deel II: fluctuaties, Rotterdam.

Ministerie van Sociale Zaken en Werkgelegenheid (1989), Rapportage Arbeidsmarkt 1989, 'sGravenhage.

Sheldon, G. (1985), Die berufliche und geographische Flexibilität, Institut für Arbeidsmarkt und Berufsforschung der Bundesanstalt für Arbeit, Beitrage AB 92, Nürnberg.

Warnken, J. (1986), Zur Entwicklung der "internen" Anpassungsfähigkeit der Berufe bis zum Jahre 2000. Projektionen unter den Annahmen der Wachstumsszenarien der PrognosStudie, in: Mitteilungen aus der Arbeidsmarkt- und Berufsforschung, no.1, blz. 119-133.

Wieling, M.H., A. de Grip, E.J.T.A. Willems (1990), Een systematische kwalitatieve typering van arbeidsmarktinformatie, ROA-W-1990/8, Maastricht. 